OPEN ACCESS

Edited by:

Bruce Christopher Glavovic, Massey University, New Zealand

Reviewed by: Stevan Harrell, University of Washington, United States Iris Borowy, Shanghai University, China

${ }^{*}$ Correspondence: H. Den Hartog harrydenhartog@ urbanlanguage.org

Specialty section: This article was submitted to Land Use Dynamics,

a section of the journal

Frontiers in Environmental Science

Received: 09 December 2020 Accepted: 09 August 2021 Published: 18 August 2021

Citation: Den Hartog H (2021) Engineering an Ecological Civilization Along Shanghai's Main Waterfront and Coastline: Evaluating Ongoing Efforts to Construct an Urban Eco-Network.

Front. Environ. Sci. 9:639739.

doi: 10.3389/fenvs.2021.639739

\section{Engineering an Ecological Civilization Along Shanghai's Main Waterfront and Coastline: Evaluating Ongoing Efforts to Construct an Urban Eco-Network}

\author{
H. Den Hartog ${ }^{1,2 *}$ \\ ${ }^{1}$ Tongji University, College of Architecture and Urban Planning, Shanghai, China, ${ }^{2}$ Faculty of Architecture and the Built \\ Environment, TU Delft, Delft, Netherlands
}

Recent ecological civilization policies make clear that China is willing to play a leading role in a sustainable green transition. But there are still discrepancies in definitions, appreciation and evaluation of ecological assets. This paper examines how Shanghai works on a sustainability transition, with a focus on its main urban waterfronts and coastline, in the context of an extremely high population concentration, world's highest real estate values, and continuous urban development pressure. This paper will mobilize insights from the academic field of sustainability transitions to show how urban planning and design ambitions are translated into realities on the ground. In its latest Shanghai Master Plan (2017-2035), the city commits itself to set an example for other Chinese cities. Moreover, Shanghai's city leaders want to inspire and push cities internationally to become more adaptable and resilient, both in the Global South and Global North. The spatially most radical action to realize this ambition is to create "a green and open eco-network" with $60 \%$ of Shanghai's municipal territory to be used for ecological purposes, mostly wetlands. This paper will examine three urban planning and design projects that have key positions within this eco-network. On all three sites there are land-use conflicts, between urban development and ecological (re-)development. The first case is the recent transformation of no less than $120 \mathrm{~km}$ of former industrial dominated waterfront along the Huangpu River, of which half was completed between 2016 and 2021. The second case, Nanhui Coastal Wetland Reserve with adjacent Lingang New City; and the third case, Chongming Eco-Island, started both around the millennium and had a 2020 planning horizon. After learning lessons from their previous sustainable innovation journeys these latter two projects entered a new phase as part of the eco-network. The paper concludes with seven practical recommendations aimed to reduce discrepancies between expectations and their implementation in practice: 1) use clear definitions; 2) co-create a shared vision for the future; 3) stop building on vulnerable locations; 4) create conditions of social learning; 5) supervision needs to go beyond planning boundaries; 6) step beyond an anthropocentric approach; and 7) foster a more experimental approach.

Keywords: ecological civilization, governance, land reclamation, low-carbon transitions, wetlands, urban delta, ecological restoration, sustainability transitions 


\section{INTRODUCTION}

\section{China's Shift to a Green Economy and the "War on Pollution"}

This paper explains and examines the ongoing transformation of Shanghai's main waterfronts in the context of a new eco-network, informed by sustainability transitions scholarship (Markard et al., 2012) and additional insights from ecological civilization philosophies (Hansen et al., 2018). The paper focuses on the Direct Controlled Municipality ${ }^{1}$ of Shanghai, because this region has an exemplary role within China in terms of testing and implementing new policies. Many city leaders see Shanghai as inspiring model, and gateway to the world with access to new ideas.

China's extremely rapid shift to urbanization this century (Hsing, 2010) resulted in prosperity and high living standards for many, but also brought collateral damage, including serious environmental pollution, declining available land and resources, and socio-economic discrepancies (Brown, 1995; Li and Shapiro, 2020; Zhao et al., 2006). Since the beginning of this century, China's policies gradually focused on the new principle of a Green Economy (Linster and Yang, 2018), which essentially turns away from the (western) idea of industrialization. Since it's eleventh Five-Year Plan (2006-2010), the People's Republic of China has committed itself to achieving a Green Economy, aimed at increasing the use of renewable energy sources, drastically reducing carbon emissions, and increasing green coverage of lands. In the twelfth Five-Year Plan (2011-2015) additional targets were added, including reversing ecological deterioration and enhancing environmental regulatory institutions. In March 2014 China declared a "war on pollution"2 and started to introduce multiple green policies. China's thirteenth Five-Year Plan (2016-2020) ${ }^{3}$ continued the lines of the previous two plans and additionally emphasized ecological restoration and protection. This year, on March 11, 2021, China's National People's Congress voted to pass the resolution on the fourteenth Five-Year Plan (2021-2025) and the 2035 long-term goal outline. This plan set $18 \%$ reduction of $\mathrm{CO}_{2}$ emissions and $13.5 \%$ of energy-intensity reduction as goals for the coming 5 years. Previous Five-Year Plans showed a trend of largely over-achieving previous set goals, and according to some observers this will likely happen again. ${ }^{5}$

\footnotetext{
${ }^{1} \mathrm{~A}$ provincial level municipality under the direct administration of the central government.

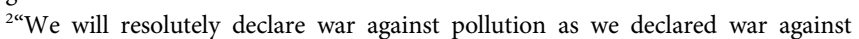
poverty," said Premier Li Keqiang at the yearly National People's Congress in March 2014. Available online on: https://www.reuters.com/article/us-chinaparliament-pollution/china-to-declare-war-on-pollution-premier-saysidUSBREA2405W20140305 (Accessed July 30, 2021).

${ }^{3}$ Available online (Chinese language): http://www.gov.cn/zhengce/content/201612/05/content_5143290.htm (Accessed July 30, 2021).

${ }^{4}$ Available online (Chinese language): http://www.gov.cn/xinwen/2021-03/11/ content_5592248.htm (Accessed July 30, 2021).

${ }^{5}$ CarbonBrief; 2021. What does China's 14th "five year plan" mean for climate change? Available online: https://www.carbonbrief.org/qa-what-does-chinas-14thfive-year-plan-mean-for-climate-change (Accessed July 30, 2021).
}

\section{Toward an Ecological Civilization}

China is demonstrating its intentions to promote Sustainable Development Goals (UN Habitat, 2015). A key driver in this aspiration is to strive to realize an ecological civilization by 2030 (Hansen et al., 2018). Ecological civilization (生态文明) can be defined as "a dynamic equilibrium state where humans and nature interact and function harmoniously" (Frazier et al., 2019). It is a socio-technical experiment. Although some scholars claim that ecological civilization originates from the western discourses on ecological modernization (Zhang et al., 2007), it has deep roots in Marxism and the potential to challenge and even replace global capitalism (Pan, 2006; Gare, 2020). It has received skeptical reactions from several international observers (Wang et al., 2014; Hansen and Liu, 2017; Wang-Kaeding, 2018). The concept of ecological civilization has been gradually integrated in the policies of the Chinese Communist Party since the 17th National Party Congress in October 2007, when it became a national strategy, as declared by General Secretary $\mathrm{Hu}^{6}$ : "Towards a new era of ecological civilization to realize the greatness of the Chinese Nation," and "ecological civilization is the key to realize the great renaissance.” In 2012, ecological civilization was included in the Party's constitution. Five years later, during the 19th Party Congress, General Secretary Xi Jinping emphasized the need to speed up realizing an ecological civilization and a more balanced model of economic growth. This transition from an industrial civilization to an ecological civilization contains three dimensions that need to be brought into harmony, according to the Communist Party's constitution: environmental, economic, and social. The elaboration of this vision and policy is a paradigm shift to a new planning approach, a journey of exploration and finding new balances, especially balances between rigid control and flexible adaptation (Xu et al., 2017; Chen and Du, 2018).

Ecological civilization calls for new balances between topdown and bottom-up governance approaches, by exploring public private partnerships and new forms of participation, as mentioned in the final chapter of Shanghai's Master Plan (20172035), in short "Shanghai 2035" (SPLRA, 2018a). To supplement this master plan ecological protection (red) lines have been introduced, i.e., zones with building limitations (see Figure 1A), to guide and control land use planning (Jin, 2020) and ecological protection around existing and planned "ecological land" (Guo, 2018). This is still in an elementary phase and during the current fourteenth Five-Year Plan (20212025) period it will become clear how this will work out in practice. Hopefully these promising expectations can be realized, in stark contrast to a previously proposed green belt in the master plan of 1999 that was completely overrun by urban use over a decade ago (Den Hartog, 2010).

\footnotetext{
${ }^{6}$ Ecological civilization is a concept proposed by Hu Jintao, general secretary of the Central Committee of the Communist Party of China in 2007. Also see this article in China Daily, available online: http://www.chinadaily.com.cn/opinion/2007-10/ 24/content_6201964.htm (Accessed July 30, 2021).
} 

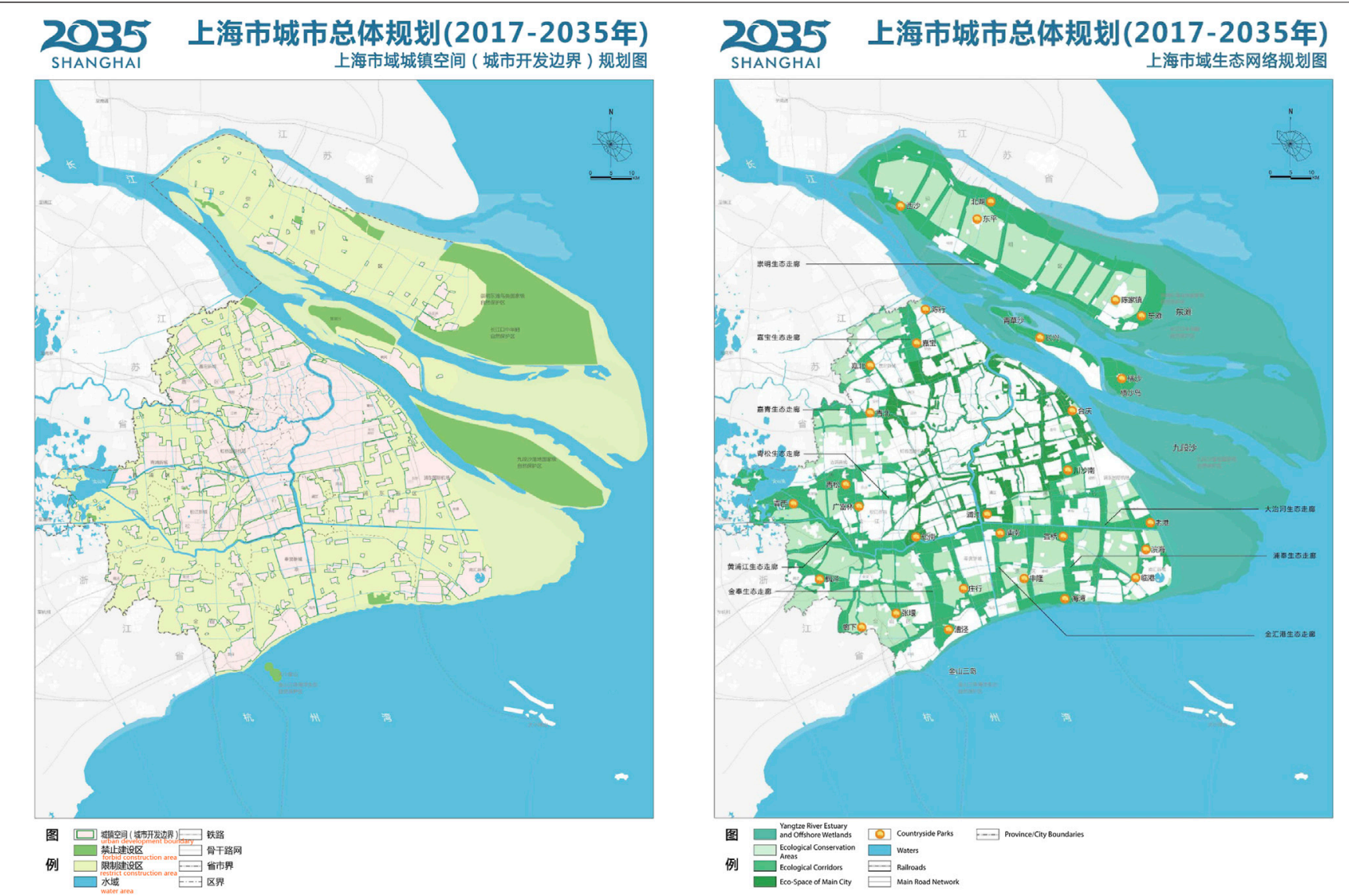

FIGURE 1 | (A) Ecological Protection (Red) Lines with building limitations (Source: SPLRA, 2018a; adjusted by author). (B) Eco-network plan of Shanghai (Source: SPLRA, 2018a; adjusted by author).

\section{Ecological Vulnerability in Urbanizing Deltas} Most wetlands are located along rivers or in river deltas. They provide directly or indirectly almost all of the world's supply of freshwater (UN Climate Change News, 2018). Approximately $40 \%$ of the world's population lives in deltas. Metropolitan regions, such as the Yangtze River Delta, the Pearl River Delta, the New York metropolitan area, Greater London, the Randstad Holland, Saigon, St. Petersburg and many others, were built on wetlands and swamps. Due to their strategic location, deltas are the location of complex land use conflicts: urbanization, infrastructures, ports, wetlands, and fertile agricultural lands compete for dominance. During last 3 decades the urbanization rate and construction of new urban areas accelerated dramatically, especially in the world's new and rising economies. China is, without doubt, frontrunner in this. As illustrated in the case studies in this paper, in the context of urbanizing deltas, wetlands often loose out. Yet wetlands are crucial ecosystems: about $40 \%$ of all plant and animal species live and breed here, and "more than $25 \%$ of all wetlands plants and animals are at risk of extinction" (UN Climate Change News, 2018).

Land reclamation, groundwater-level lowering, and other urban influences have diminished wetlands worldwide. The world's wetlands are disappearing three times faster than forests; nearly 35\% of all wetlands were lost between 1970 and 2015 (UN Climate Change News, 2018). Since 2000, this process has been accelerating. Worldwide, policy provisions and decision-makers undervalue wetlands according to a report by the global Wetland Convention (UN Climate Change News, 2018); and there is a lack of urban wetland management and policy guidance. Usually there are tensions between conservation and development. However, wetlands have a range of important ecosystem services (Danley and Widmark, 2016), such as rainwater storage or sponge capacities, storm surge protection (Moeller et al., 2014), water purification, carbon sequestration (Sutton-Grier and Howard, 2018), biodiversity conservation, but limited options for urban recreation (limited to protect the wetlands).

Aside from some inland metropolises, such as Chongqing, Chengdu, and Wuhan, most of China's urbanization boomed in a zone of approximately $100 \mathrm{~km}$ along its coastline, with extremely high concentrations in the three main delta areas: the Pearl River Delta, the Bohai Rim (Tianjin and Beijing), and the Yangtze River Delta. This rapid growth brought a new urban lifestyle, and improvements in the quality of life for millions. It also brought new problems, such as air pollution, water quality problems, and ecological degradation. 


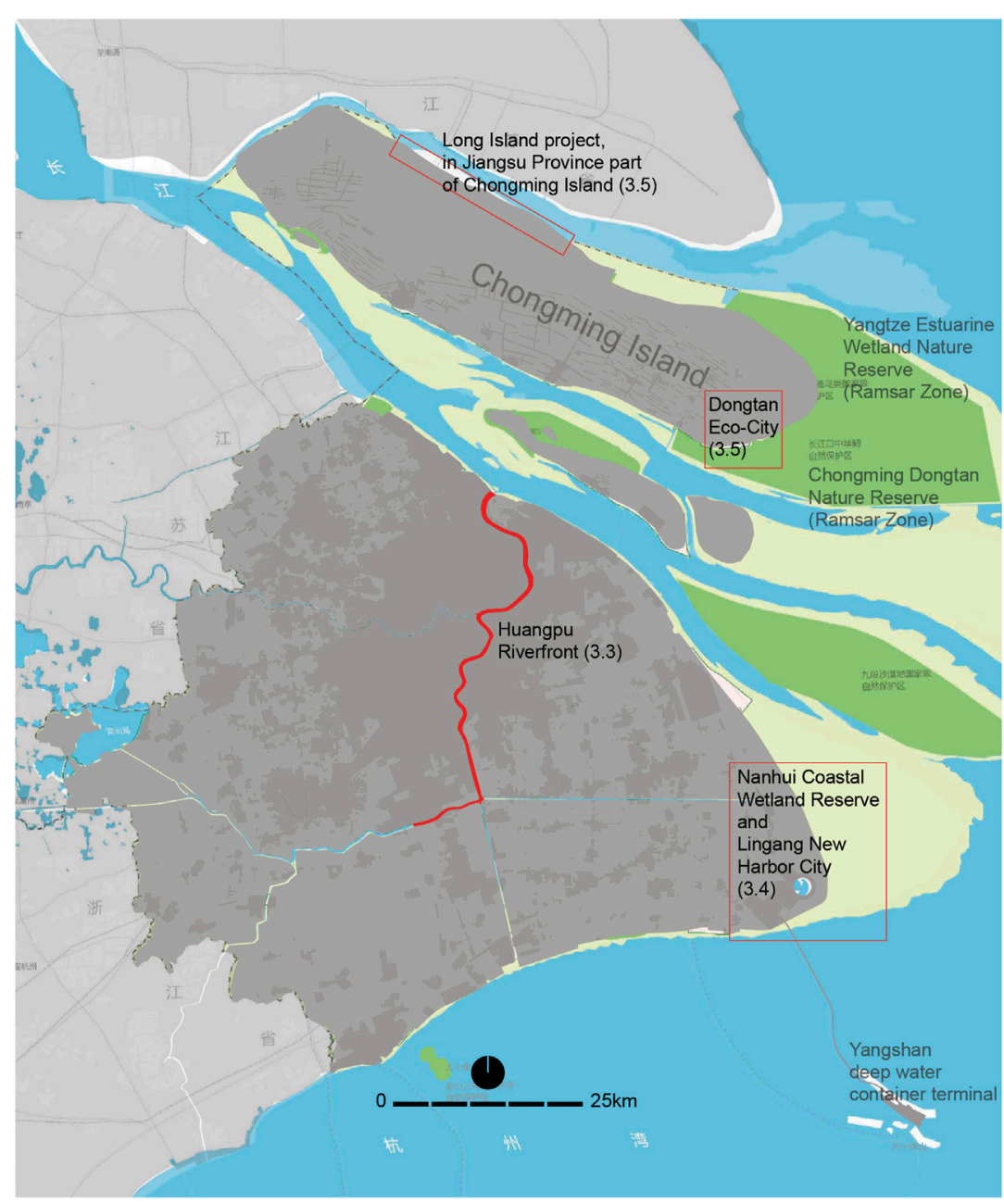

FIGURE 2 | Shanghai Direct Controlled Municipality with the locations mentioned in this article (image by author; green zones as underlay by SPLRA, 2018a).

Since the 1950's more than half of China's coastal wetlands disappeared, $53 \%$ of temperate coastal ecosystems, $73 \%$ of mangroves and $80 \%$ of near-shore coral reefs vanished, according to research by China's State Forestry Administration, Chinese Academy of Science's Institute of Geographic Sciences and Natural Resources Research, and the Paulson Institute, ${ }^{7}$ mainly because "huge economic returns from land reclamation have prompted local governments to 'bypass' regulations issued by the central government" (Larson, 2015). Sea reclamation is a relatively quick ${ }^{8}$ and cheap way to get more land and profits. Another reason is competing policies, e.g., local authorities are required to safeguard food supply by

\footnotetext{
${ }^{7} \mathrm{~A}$ full report can be queried online via: https://www.paulsoninstitute.org/ conservation/wetlands-conservation/blueprint-of-coastal-wetland-conservationand-management-in-china (Accessed July 30, 2021).

${ }^{8}$ In many recent Chinese cases the construction of buildings start already within a year, for example in the case of the Long Island project on Chongming (Den Hartog, 2017). However, land needs at least 4 years to get firm and solid, according to Dutch experiences, to prevent damage by subsidence.
}

maintaining a minimum amount of arable land, ${ }^{9}$ consequently allowing wetlands-which are often classified as wasteland ( $\mathrm{Li}$, 2019) - to be cultivated for farming.

The concept of protecting nature by law is relatively new in China. China's first nature reserve was established in 1990 in Shanghai; consequently in this same city public awareness about environmental issues started to increase gradually (Zhao et al., 2006). This pioneering role of Shanghai will be explored further with help of theoretical framing and case studies in the next sections, to examine the achievements and hurdles in Shanghai's ongoing journey towards an ecological civilization.

${ }^{9}$ Since 2004 the Communist Party has set a red line for China's total arable land, which shall be no less than 1.8 billion mu (120 million ha). See: https://news.cgtn. com/news/3d3d514d316b444f32457a6333566d54/index.html (Accessed July 30, 2021) 
CASE INTRODUCTION AND THEORETICAL FRAMING

\section{Aims and Case Selection}

This research aims to test how sustainability transitions "thinking" (see Sustainability Transitions and Experiments) can be applied in a useful way in the context of Shanghai, with additional insights from ecological civilization "thinking." This paper critically assesses how Shanghai seeks to implement large-scale ecological improvements along its interface between land and water, in former port areas and along the continuously shifting coastline, in the context of extreme urbanization pressure. How is Shanghai dealing with the expectation of a sustainable green transition, and what can we learn from this? How is the city seeking to improve the balance between wetland protection, urban development, and climate change adaptation?

The cases (Figure 2) are located along Shanghai's main waterfronts and illustrate conflicts between urban development pressure and ecological values. The first case (Huangpu River Waterfront as Main Stage for Ecological Civilization) is the Huangpu River's waterfront transformation in the central city, where former port-related industries make place for a new service-oriented economy (Den Hartog, 2021). The second case (Nanhui Coastal Wetland Reserve and Lingang New Harbor City) deals with wetland development that conflicts with Lingang New Harbour City and relocated port areas on large-scale land reclamations along Pudong District's coastline. The third case (Chongming Eco-Island) deals with speculative peri-urban new town developments along the edge of Chongming Eco-Island located in the Yangtze River estuary. All three cases form crucial elements in an engineered new eco-network (Figure 1B; see A Green Eco-Network as Socio-Technical Experiment to Support the Transformation of Shanghai into an Ecological Civilization).

\section{Sustainability Transitions and Experiments}

Drawing on insights from scholarship on sustainability transitions and additional insight from ecological civilization (as a National socio-technical experiment), this paper examines how planning ambitions are translated into local realities on the ground, during their planning and implementation process, and afterwards. In the field of sustainability transitions, scholars investigate major shifts toward sustainable socio-technical systems of production and consumption (Markard et al., 2012). Following the main conceptualization of sustainability transitions, which predominantly originate from North- and Western European countries with strong welfare state traditions, some overarching patterns can be identified (Sengers et al., 2016; Kivimaa et al., 2017; Weiland et al., 2017), which are translated into comprehensive lessons on how urbanization processes can be guided towards more sustainable pathways to create attractive and functional new (urban) environments. For this paper, three core concepts from this body of theory are used to frame the empirical analysis and argumentation: 1) expectations, 2) sociotechnical experimentation and 3) sustainable innovation journey.
The concept of "expectations" is often used in the field of sustainability transitions to explore how actors use appealing visions of a sustainable future in their (urban) development projects. These expectations can be defined as "statements about the future that circulate" (Van Lente, 2012). This idea of circulation is important, because expectations are "performative" by helping to create a new future reality by coordinating roles and activities amongst actors (Konrad, 2006) and by legitimizing certain investments (Borup et al., 2006). Hence expectations should be robust (shared by multiple actors), specific, and of high-quality (Schot and Geels, 2008).

To translate these expectations into realities on the ground, actors need to participate in a process of "socio-technical experimentation" (Evans et al., 2016). The expected creative and innovative solutions are tested and developed in real-life settings or urban labs. ${ }^{10}$ While testing, a wide variety of societal stakeholders are involved. There are also other external influences that can define the outcome. Unlike experimentation in the natural sciences-that usually takes place under strictly controlled conditions, aimed to find objective certainties-experimentation in the field of sustainability transitions is an open-ended process. Consequently, scholars talk about "socio-technical experiments," which are an: "inclusive, practice-based and challenge-led initiative, designed to promote system innovation through social learning under conditions of uncertainty and ambiguity" (Sengers et al., 2016). Experiments are only meaningful if involved actors are willing to engage and foster social learning, and are open to system innovation when prioritizing their set sustainability goals (Loorbach, 2007).

Socio-technical experimentation in the urban environment is accompanied by an open-ended unfolding innovation journey (Van de Ven et al., 1999), in particular a "sustainable innovation journey" (Geels et al., 2008), full of uncertainty (Garud et al., 2014). In the case studies in this paper of this paper a narrative perspective is used to describe these journeys.

In Chinese urban planning and design we can distinguish three types of experiments:

(1) "Pilot-projects" aimed to (re)formulate relevant policies (e.g. a "low-carbon pilot"; Den Hartog et al., 2018);

(2) "Demonstration projects" (or zones) are considered to be successful experiments that can be replicated (e.g., Chongming Island as National Ecological Demonstration Zone; Ma et al., 2017);

\footnotetext{
${ }^{10}$ For example the "Hunts Point Resiliency" pilot-project in the Bronx, New York City, available online: www.rebuildbydesign.org/our-work/all-proposals/winningprojects/hunts-point-lifelines and https://medium.com/hunts-point-resiliency (Accessed July 30, 2021); or the Living Breakwaters Staten Island, New York City, available online: http://www.rebuildbydesign.org/our-work/all-proposals/ winning-projects/ny-living-breakwaters and https://stormrecovery.ny.gov/learnmore-about-living-breakwaters-project (Accessed July 30, 2021); or the multiple samples in Rotterdam, see: https://www.c40.org/case_studies/c40-good-practiceguides-rotterdam-climate-change-adaptation-strategy (Accessed July 30, 2021).
} 
(3) "Civilized projects" are excellent social management models that support political principles (e.g. Wusong Paotaiwan Wetland Forest Park ${ }^{11}$ ).

The concepts of sustainable development and sustainability follow the definition of The Brundtland Report, which states: "Humanity has the ability to make development sustainable to ensure that it meets the needs of the present without compromising the ability of future generations to meet their own needs" (United Nations, 1987).

\section{Research Methodology}

Empirical evidence for this research is based on site observations, document analyses, and fieldwork by the author. A foundation for data collection was laid during fieldwork with students at the Shanghai University of Finance and Economics as part of the authors' course "city and environment," between 2015 and 2019. During thirty site visits there were short conversations with local people, including farmers, and more in-depth conversations with key-stakeholders, including local officials, entrepreneurs, nature conservation specialists, and urban planners. During fieldwork, design studios and workshops at Tongii University there were more detailed investigations for all three cases (Huangpu River Waterfront as Main Stage for Ecological Civilization, Nanhui Coastal Wetland Reserve and Lingang New Harbor City and Chongming Eco-Island). Desktop research was carried out to review sustainability transitions and ecological civilization literature, and relevant planning documents at the municipal and national level (when needed with translation and interpretation). The author co-organized and participated in knowledge exchange projects in cooperation with various universities in Shanghai and abroad. ${ }^{12}$

The study has some limitations. Although translation was continuously available, the interpretation may be viewed differently in some situations. In the Chinese context, access to reliable numerical data can be difficult. Hence a qualitative research approach has been used in this study.

\section{SHANGHAI'S WATERFRONTS AND COASTLINE AS A LABORATORY FOR ECOLOGICAL CIVILIZATION Strategic and Exposed Position in the Yangtze River Estuary}

The origin of Shanghai is inseparable from its location beside the water. ${ }^{13}$ An efficient network of waterways (Ball, 2017; King, 1911) shaped the spatial and economic development of the Yangtze River Delta. Shanghai's waterfronts can be seen as a

\footnotetext{
${ }^{11}$ CGTN (2018). Shanghai turns a steel slag field into a wetland forest park. Available online: https://news.cgtn.com/news/ 3d3d674d3351444e79457a6333566d54/index.html (Accessed July 30, 2021).

${ }^{12}$ The cases in this paper were the subject of previous studies by author: Chongming Island (Den Hartog, 2017; Ma et al., 2017; Den Hartog et al., 2018; Den Hartog, 2019), Nanhui (Den Hartog, 2010), and the Huangpu River's waterfront (Den Hartog, 2019; Den Hartog, 2021).

${ }^{13}$ The city's name literally translates as "upon the sea."
}

Frontier where conflicts in land use manifest between land reclamation, urban use, industrial use, agricultural use, and natural conservation. Shanghai's location on the estuary brought prosperity, especially as a result of port activity. It also brought exposure and vulnerabilities: scarcity of fertile lands (Brown, 1995), increasing flood-risk (Balica et al., 2012; Hanson et al., 2011; Ke, 2014; Quan, 2014), and endangered wetlands (Wang, 2012; Li et al., 2020).

Along the coastline there has always been a strip of wetlands that grew by a natural process of sedimentation. This process of an eastward shifting coastline largely created the territory of Shanghai. Especially since the 1950s, this process has been accelerated by means of breakwaters and land reclamation. Under Mao's leadership, there was a shift toward technocratic engineering: "Man must conquer nature" (Shapiro, 2001). Natural capital and landscape values were neglected. Moreover, urban planning practices were principally based on a tabula rasa approach, which largely ignores existing natural and cultural-historical values. Many natural waterways in this region were transformed into canals, while others were dammed or filled in completely. Supported by the new principles of the socialist market economy, financial motivations (Harvey, 2005) began to dominate planning and land-use practice, often with additional collateral damage for ecosystems and quality of life for residents (e.g. various forms of pollution, resettlement). Increasing land scarcity forced Shanghai to create new land through land reclamation.

Besides changes in sedimentation due to a decrease in discharge after construction of the Three Gorges Dam in 2003 (Yang et al., 2005), the wetlands along Shanghai's coastline became increasingly under threat by land reclamation. Approximately $40 \%$ of Shanghai's estuarine wetlands have been lost since 1980 due to land reclamation, totaling $816.6 \mathrm{~km}^{2}$ between 1974 and 2018 (Li et al., 2020). The main uses of the reclaimed lands have been agriculture and urban expansion-planned new town construction on Chongming Island (see Chongming Eco-Island), and Lingang New Harbor City (see Nanhui Coastal Wetland Reserve and Lingang New Harbor City), Pudong International Airport, tap water storage areas, recreation (golf), and port relocation (from the Huangpu River to along the coastline).

A decade ago scientists warned that Shanghai faced a serious risk for a "once in a 100 years flood," with serious consequences, ${ }^{14}$ and possible economic impacts far beyond the city (Balica et al., 2012; Hanson et al., 2011; Ke, 2014; Quan, 2014). Since then substantial flood protection measures have been implemented along the Huangpu River, in the form of 7-m high retaining walls. Also, in the Pudong District, coastal dikes have been reinforced, and make Shanghai-except Chongming Island-better prepared for flood risk compared to some other financial centers (Xian et al., 2018; IPCC, 2019).

These efforts have been convincingly combined with the regeneration of polluted industrial waterfronts and

\footnotetext{
${ }^{14}$ Also see this animation by Climate Central's Program on Sea Level Rise, available online: https://choices.climatecentral.org/\#11/31.2307/121.4738? compare $=$ temperatures $\&$ carbon-end-yr $=2100 \&$ scenario- $a=$ warming- $4 \&$ scenario$\mathrm{b}=$ warming-2 (Accessed July 30, 2021).
} 


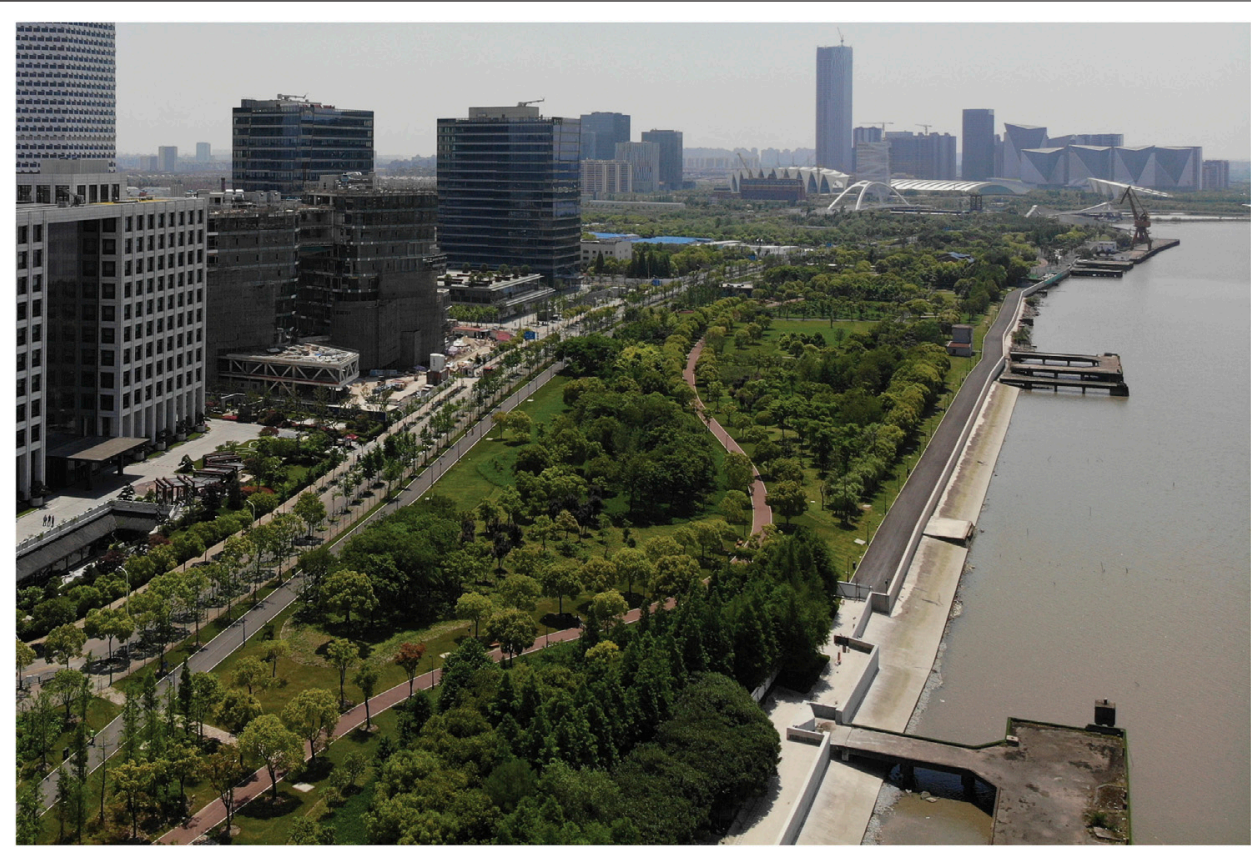

FIGURE 3 | Hard embankments in new ecological park along the Huangpu River (Photo by author, September 2020).

construction of beautiful manicured public spaces (Den Hartog, 2019). However, the 'hard' technocratic solutions with flood prevention infrastructure (Figure 3) constitute barriers for ecological development, e.g., concrete embankments do not provide nesting opportunities for fish, birds, and other species and will need to be addressed (Gan et al., 2018).

Along the coastline of Nanhui (see Nanhui Coastal Wetland Reserve and Lingang New Harbor City), many wetlands (including salt marshes, mud flats and portions of the estuary water body) have been diked-constructed at $2 \mathrm{~m}$ depth below the minimum low-tide level-to speed up siltation reclamation for urban purposes (Tian et al., 2015) instead of benefitting from the storm surge protection capacities of wetlands (Moeller et al., 2014) - and converted into aquaculture farming or agriculture, which adds to flood risk (Cui et al., 2015). To compensate for the collateral damage of extreme rapid urbanization, Shanghai has been searching for ways to protect existing wetlands and stimulate the development of new wetlands, which currently looks like more of an ecological engineering effort than ecological restoration, as will be described in the next sections.

\section{A Green Eco-Network as Socio-Technical Experiment to Support the Transformation of Shanghai into an Ecological Civilization Promising Expectations in "Shanghai 2035"}

Following the master plan's promising subtitle "Striving for an Excellent Global City" Shanghai wants to compete with, and possibly surpass, other global cities such as New York, London, Paris, Singapore, and Tokyo in terms of economy, image, and quality of life. Shanghai commits itself to become a benchmark for international megacities in terms of green, low-carbon and sustainability" (SPLRA, 2018a). Shanghai 2035 further states: "the world has stepped into an era of ecological civilization that puts environmental friendliness and a humanistic approach first." By developing multiple pilot-projects Shanghai wants "to play a pioneering role" and "take the lead" by becoming an "environment-friendly, economically-developed, culturally-diversified, safe and livable city" (SPLRA, 2018a). In poetic words, the master plan further states that "citizen happiness" is fundamental to development, and because of this, "Shanghai strives to build a prosperous and innovative city." According to the master plan Shanghai also wants to become more adaptable to climate change and resilient. All of this should be realized by engineering "a desirable ecological city," which is explained as "a beautiful space that meets the demands of the increasing number of citizens, where the water is more blue and the land is more green, and one lives in harmony with nature [...] to satisfy the citizens yearning for a better life" (SPLRA, 2018a). The two terms "beautification" and "harmonization" have been increasingly used in ecological civilization campaigns since 2007 (Hansen et al,, 2018). The realization of an ecological civilization is a nationwide socio-technical experiment, for which Shanghai will play a guiding and pioneering role. In 2015, local authorities started constructing an Overall Plan for Ecological Civilization System Reform, which has been integrated in the master plan Shanghai 2035.

\section{Socio-Technical Experimentation With Green Infrastructure}

A key project in this sustainable innovation journey toward an ecological civilization is the construction of a blue and green interconnected eco-network with at least $60 \%$ of the municipal territory restored or conserved for ecologic functions (Figure 1B), which is an increase of ten percent. Extensive new wetlands and a variety of ecological restoration and engineering projects are planned, 
ranging from national parks (two on Chongming), city parks, and $+1,000$ - $\mathrm{m}$ wide green corridors to community-based pocket parks and vertical greenery on buildings. Many of these green spaces have already been implemented since 2017, partly accelerated and prioritized due to the Covid-19 crisis. Similar to the Green Belt around London and other green buffers, such as the Green Heart of the Randstad metropolis in the Netherlands, a main function of Shanghai's new eco-network is to "satisfy citizens' diversified leisure demands," but also to enhance ecological diversity (SPLRA, 2018a). The eco-network aims to get citizens closer to nature and reconnect the city with the countryside, explained as the so-called "introducing the forest to the city"-policy (SPLRA, 2018a). Moreover, this green infrastructure is mentioned as a new backbone for urban development (instead of rails or asphalt).

\section{Sustainable Innovation Journey Toward an Ecological Civilization}

In the early phase of implementing this eco-network, many local hurdles became apparent and limited anticipated ecological connectivity (Liu et al., 2019). The experimental projects, as described in the next three sections, are important components in this eco-network. Each started early this century, and important lessons can be distilled from their sustainable innovation journeys. A main problem is a lack of clarity about the definition of "ecological land" (as explained in Sections Nanhui Coastal Wetland Reserve and Lingang New Harbor City and Chongming Eco-Island), resulting in a mismatch between outcomes and expectations. Ecological land is defined in Shanghai 2035 as "land that is used to provide ecosystem services in the city, including green land, forest land, garden land, cultivated land, tidal flat reed land, pond aquaculture water surface, unused lands, etc." (SPLRA, 2018a). In fact this appears to be all the land that is not build upon or paved, and it even includes large water surfaces (compare Figures 1A,B with Figure 2: grey color on Figure 2 is current land surface). Hence, the ecological value of these spaces obviously varies. Shanghai's rapidly increasing number of roof gardens and green facades can have ecological value, and at the same time, there are un-built and unpaved lands that have less ecologic value such as golf courses.

\section{Huangpu River Waterfront as Main Stage for Ecological Civilization Expectations and Socio-Technical Experimentation}

Shanghai's most spectacular project is the urban regeneration of the Huangpu River's waterfront that used to be dominated by portrelated industries. The river is intended to become a key component of the envisaged eco-network, ${ }^{15}$ a "green and lowcarbon demonstration zone" (SPLRA, 2018a), and crucial contributor to realize the aspiration of an ecological civilization. In the context of extreme urban density, the riverfront is expected to form a continuous open public space as "urban living room", to emphasize Shanghai's identity as a port city, and to create new

\footnotetext{
${ }^{15}$ According to the Shanghai Huangpu River and Suzhou River planning (SPLRA, 2018b) the ecological space along the Huangpu River will increase with 1,000 ha "to improve the ecosystem, improve the quality of space, and build an excellent global city."
}

ecological connections (Figure 1B). It is simultaneously the main contributor to becoming an "Excellent Global City." In 2018, the Huangpu Waterfront became officially a "demonstration zone for the development capability of the global city of Shanghai" (SPLRA, 2018b). The importance of this project is underlined by an inspection visit of a section of the waterfront in Yangpu District-within the overall demonstration zone this relative short section is earmarked as demonstration zone for the construction of a people-oriented city (Figure 4)-by General Secretary Xi November 2019, ${ }^{16}$ and a possible revisit during Summer 2021, most likely followed by a visit of Chongming Island.

\section{Sustainable Innovation Journey}

Combining urban regeneration of former industrial waterfronts with ecological development is an immense challenge, especially due to increasing land scarcity, towering real estate prices, and the necessary integration of a flood defense system. Most polluting industries have already been relocated to beyond the edge of the city (e.g. along the coast of the Pudong district and on Chongming Island) with more space to grow, and even to other provinces. Plans are underway to relocate the last remaining industries, such as the government-owned Baosteel (see Expectations and Socio-Technical Experimentation), the second largest steel producer in the world. This measure adds to the reduction of carbon emissions within the city limits and improves the general image and quality of life-to make place for a scenic recreational landscape. In less than 5 years, a very attractive more than $50 \mathrm{~km}$ of public waterfront with greenery, and biking and walking trails emerged along the Huangpu, offering a welcome and pleasant relief of the urban congestion.

Yet the new greenery along the Huangpu River is maintained with a people-oriented approach. As observed during field research, pesticides are frequently used to control the manicured newly green landscape. Decorative flowers (good for taking selfies) are preferred instead of the spontaneous growth of species. To accommodate urban use and set priorities for certain areas within the limited available space, zoning has been proposed by experts from Tongji University (Figure 5A) with four different categories: 1) "Eco for charming," which means decorative green in a high-density urban context (Figure 4); 2) "Eco for sharing," in a context with more space for green that can be used for recreational purposes; 3) "Eco for symbiosis," in a residential context; 4) "Eco for wilderness," which is not accessible to people. In the first three categories, the principle of socalled stepping-stones has been introduced, which means the creation of micro-greens for birds and other species that can hop from one stepping-stone to another one, adding to ecological corridors (Gan et al., 2018). A stepping-stone could be an eco-friendly architectural feature for breeding and shelter (e.g. green walls and roofs), a small (floating) island, or ecological hanging bags along embankments, or ecological slopes. After the urban planning bureau of Shanghai adjusted the proposal (Figure 5B), dozens of stepping-stones were introduced (Figures 4, 6, 7). "Eco for wilderness" is yet to be found along the Huangpu River, but hopefully this will be realized by 2035, at

\footnotetext{
${ }^{16}$ Impressions available online on: http://www.xinhuanet.com/english/2019-11/02/ c_138523489_2.htm (Accessed July 30, 2021).
} 


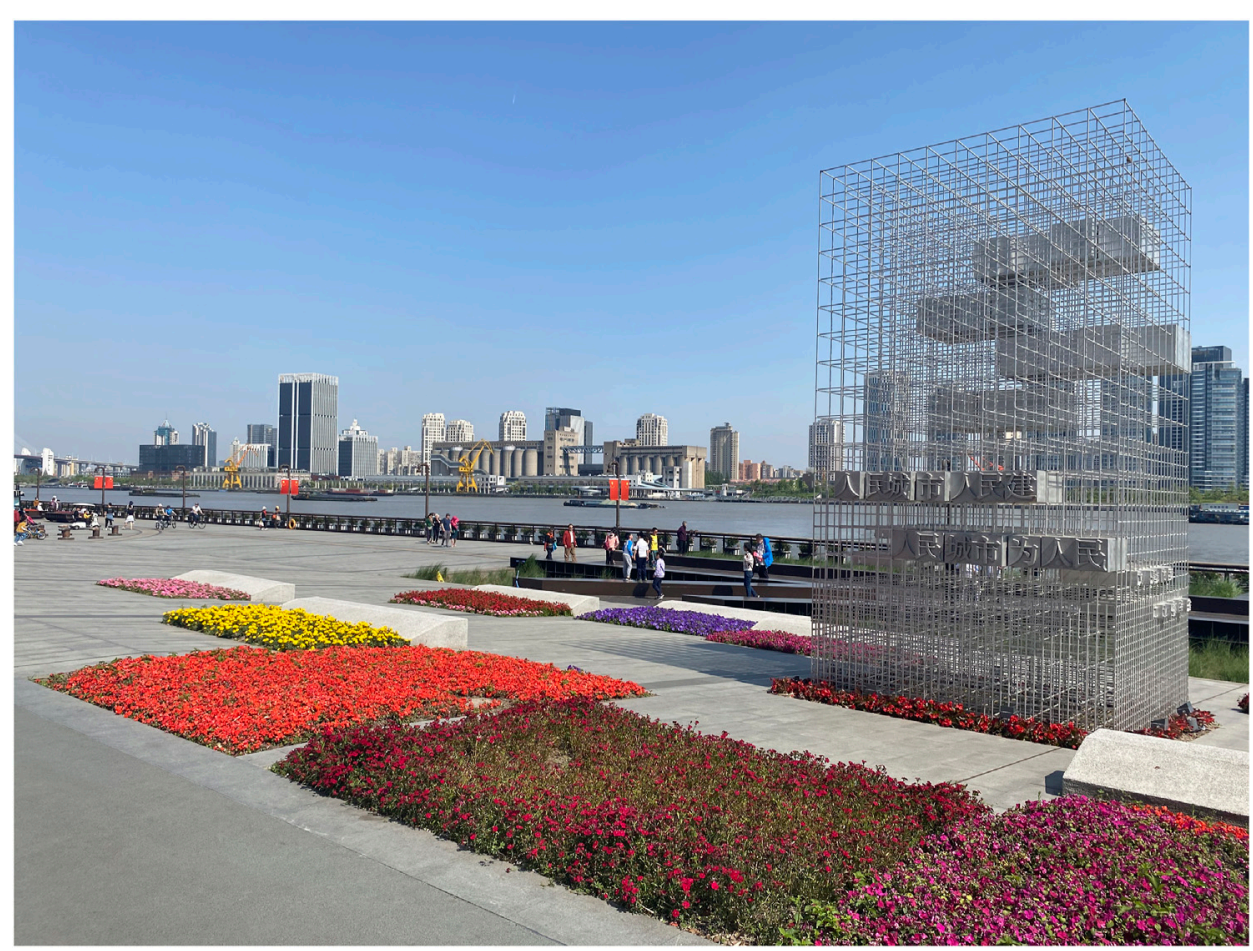

FIGURE 4 | People oriented "Eco for charming" along the Huangpu River in Yangpu District (Photo by author, May 2021.

the end of the journey, as set in Shanghai's master plan. Priority has been given to removing polluting industries and improvement of the area's public image with manicured greenery. A next step in the ongoing sustainable innovation journey is expected to add more ecological values.

The greening projects so far formed the setting for massive real estate projects that were constructed here from 2012 (Den Hartog, 2021). All these new buildings received green labels to match the National Green Building standard, especially regarding low-carbon emissions. Although in practice the application of these standard is still questionable (Den Hartog et al., 2018), and a very large share of the newly built buildings is used for speculation purposes and remain mainly empty even several years after completion and before the COVID-19 crisis started (Den Hartog, 2021).

\section{Nanhui Coastal Wetland Reserve and Lingang New Harbor City Expectations and experimentation to create a "future coastal city"}

Another locality that embodies the clash between urbanization pressures and ecological protection or restoration is the Nanhui Coastal Wetland Reserve (Figures 2, 8, 9) at the edge of Shanghai's Pudong District, under the flight path to Pudong International Airport. A significant portion of this $122.5 \mathrm{~km}^{2}$ land reclamation project is earmarked for urbanization. In 2002, when the area was a tidal flat, it was expected that the pilot project Lingang New Harbor City would grow here into a city with 800,000 inhabitants by 2020 (Den Hartog, 2010). This new city accompanies the Yangshan Deep-water Port complex, which opened in 2010, today the largest container terminal in the world in terms of capacity. Nearby new (heavy) industry complexes have been erected, partly as a relocation area for the regenerated waterfronts along the Huangpu River downtown. The promising expectation was to create a "future coastal city" with advanced manufacturing, shipping trade, and marine industry. Lingang New Harbor City was expected to function as "demonstration zone of reform and opening-up, driven by system innovation" and "intellectual and cultural innovation."

\section{Sustainable Innovation Journey and Conflicts With Wetland Restoration Efforts}

But, due to the remote location, lack of facilities, and poor building conditions (many buildings suffer serious moisture problems), as well as fluctuations in the expected port development and international container transport, the sustainable innovation journey of this new city stalled. More than half of the realized buildings were still empty in 2021. About three quarters of the planned city actually has yet to be built. Under influence of the nearby Ramsar zones ${ }^{17}$ on Chongming Island, the coast of Nanhui became an important transit area for migratory birds, with rich biodiversity. According the original

\footnotetext{
${ }^{17}$ Chongming Dongtan Nature Reserve, Shanghai, https://rsis.ramsar.org/ris/1144; Shanghai Yangtze Estuarine Wetland Nature Reserve for Chinese Sturgeon, https:// rsis.ramsar.org/ris/1730 (Accessed July 30, 2021).
} 

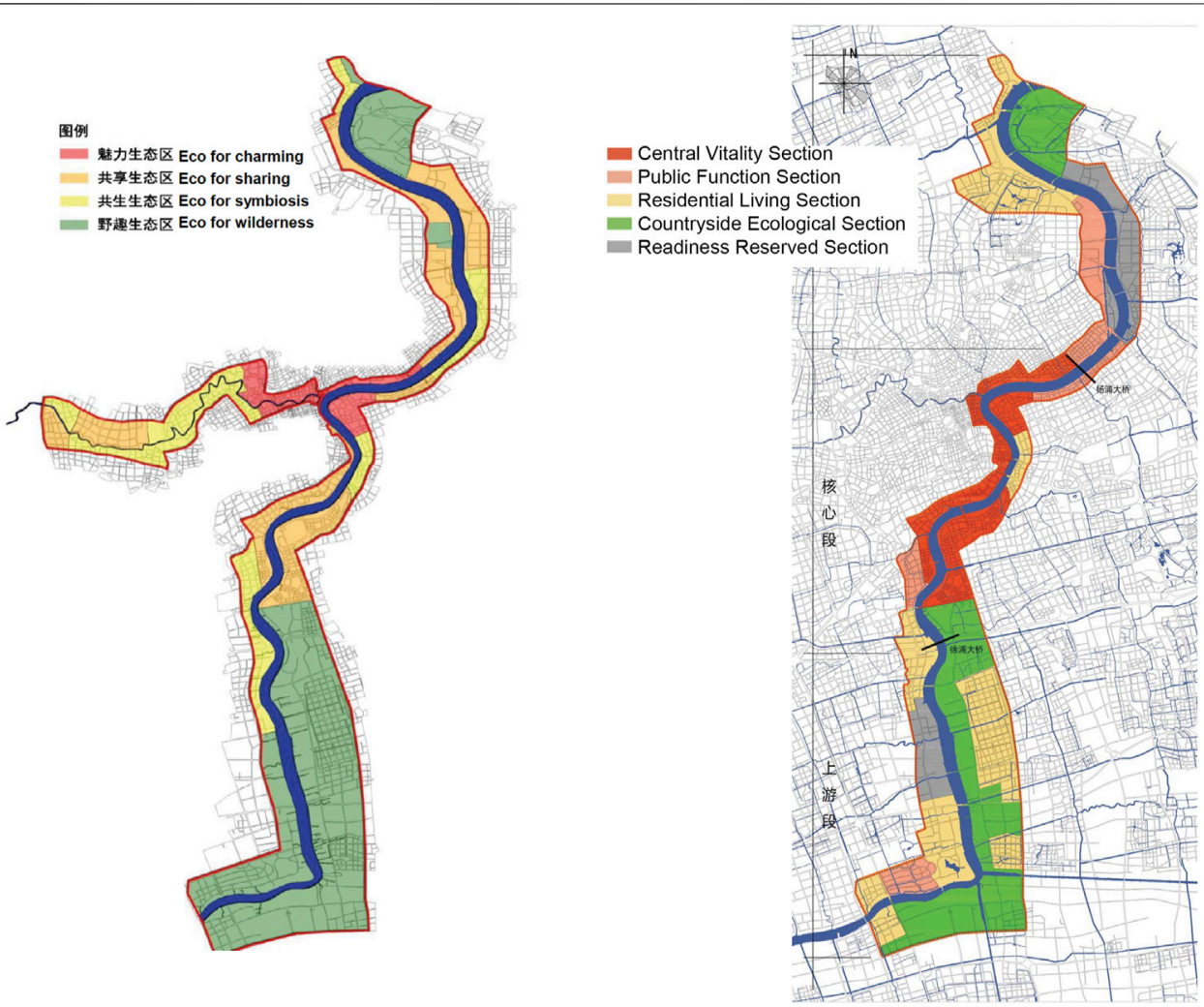

FIGURE 5 | (A) Proposal for ecological dimensions along the Huangpu River (Source: Gan et al., 2018). (B) Functional zones along the Huangpu River according to municipal planning bureau (Source: SPLRA, 2018a).

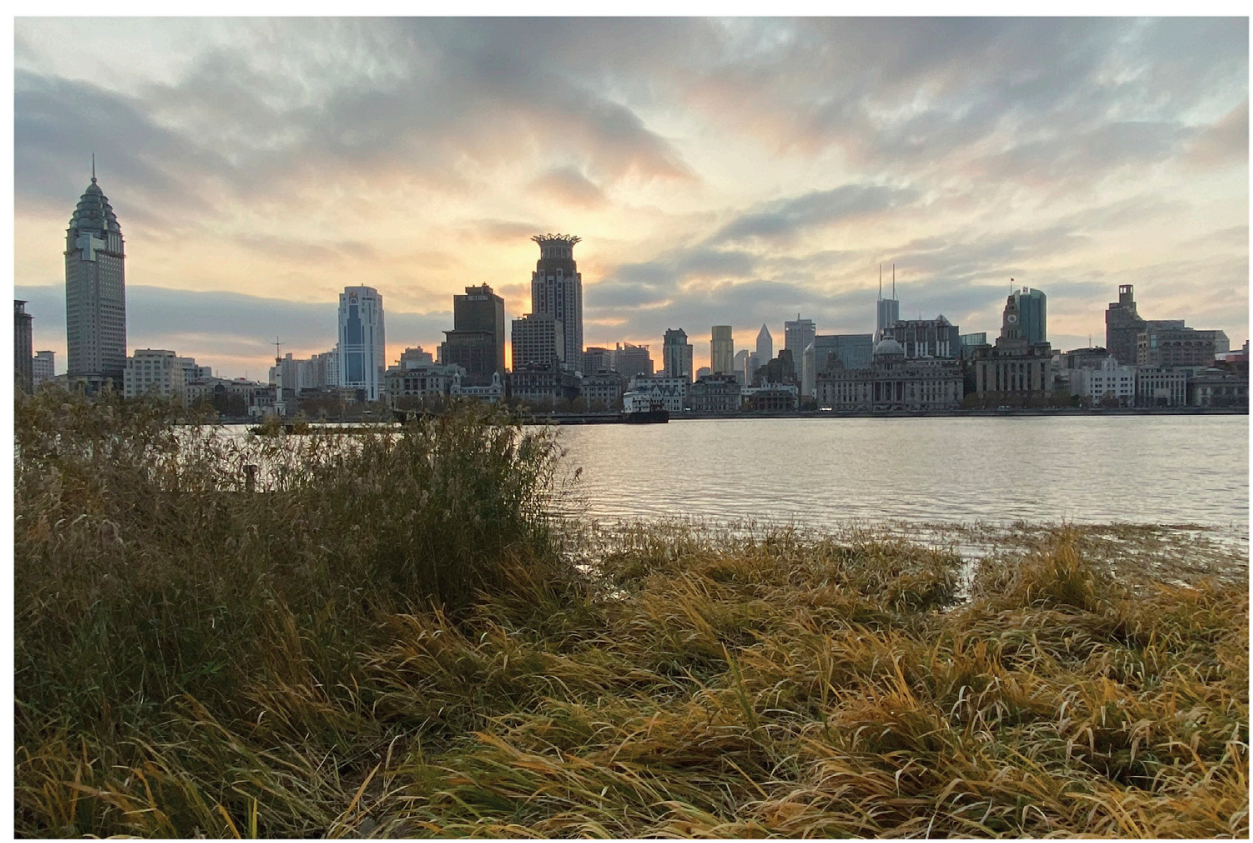

FIGURE 6 | Ecological 'stepping-stone along the Huangpu River at Lujiazui, the city center (Photo by author, March 2020. 


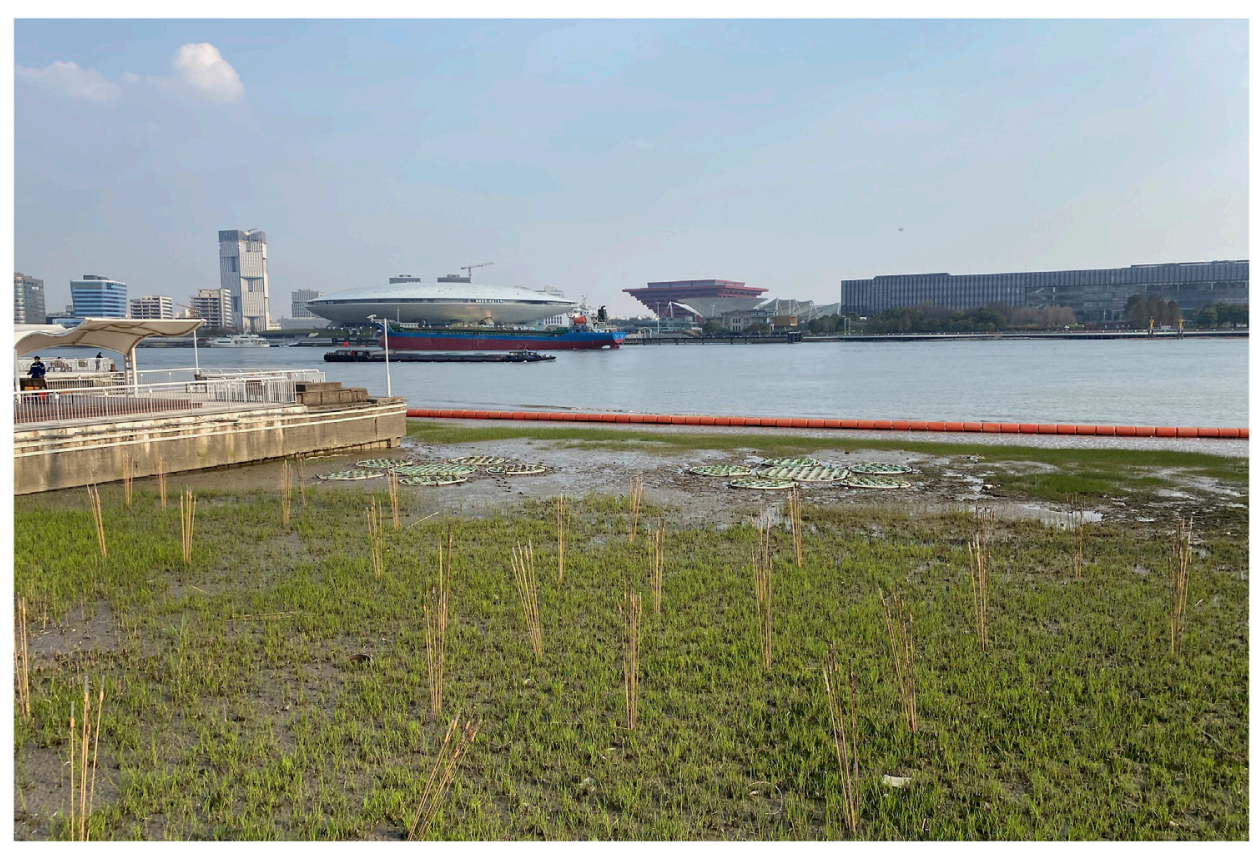

FIGURE 7 | Ecological 'stepping-stone along the Huangpu River at the former World Expo 2010 site (Photo by author, March 2020.

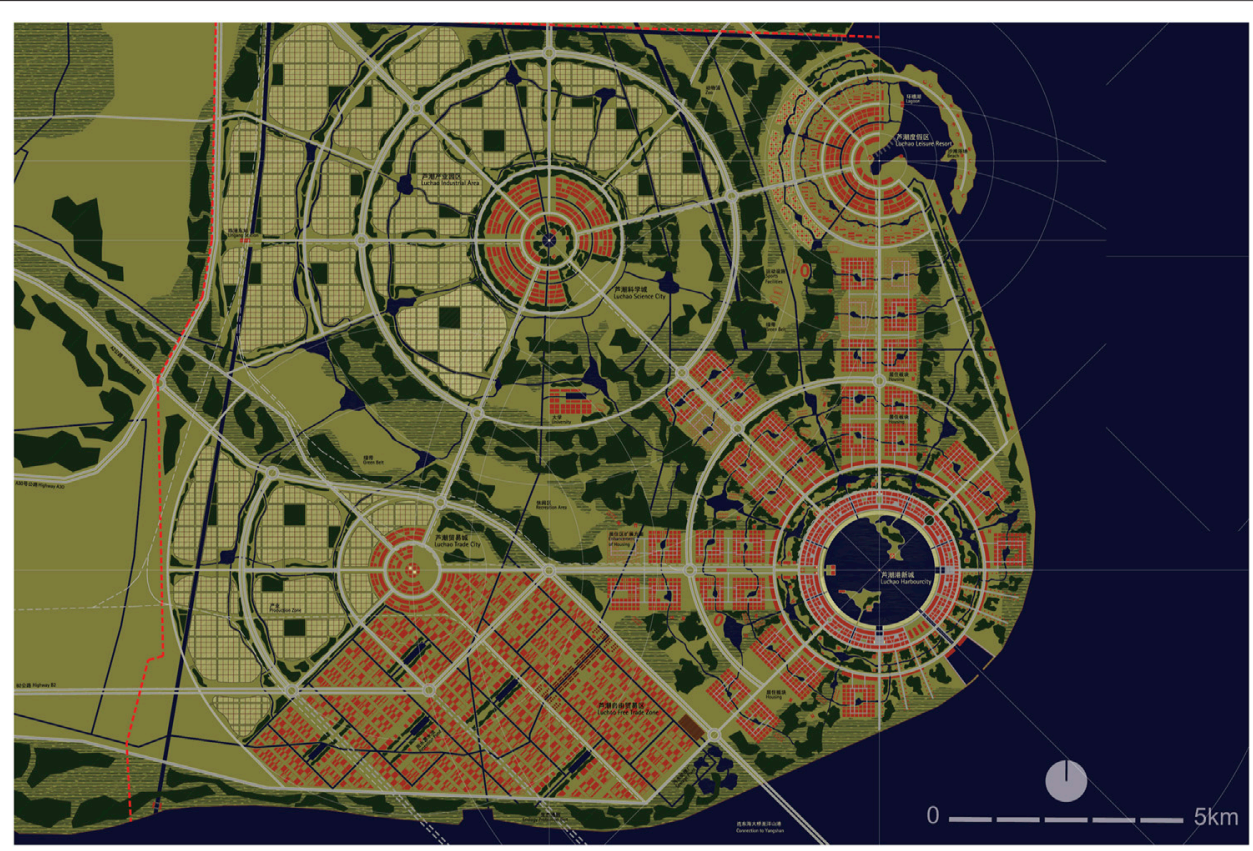

FIGURE 8| Master plan Lingang New Harbor City with 800,000 inhabitants on top of 122.5 square kilometers reclaimed wetland. Only a quarter of this city and its green buffers has been realized, a large share of the buildings is empty and remaining lands have various usages, mainly farming or recreation (Source: GMP 2001; adjusted by author).

plan, the new city was to be surrounded by lush nature and wetlands. However, a large part of the lands reserved for nature development currently has other land-uses, such as aqua farming and plantations. From an agricultural point of view, wetlands are often seen as wastelands ( $\mathrm{Li}, 2019)$ and farming, including aquaculture is prioritized above nature conservation, especially in times of increasingly scarce agricultural resources (Brown, 1995). Wetlands are even defined as unused land in China's land 


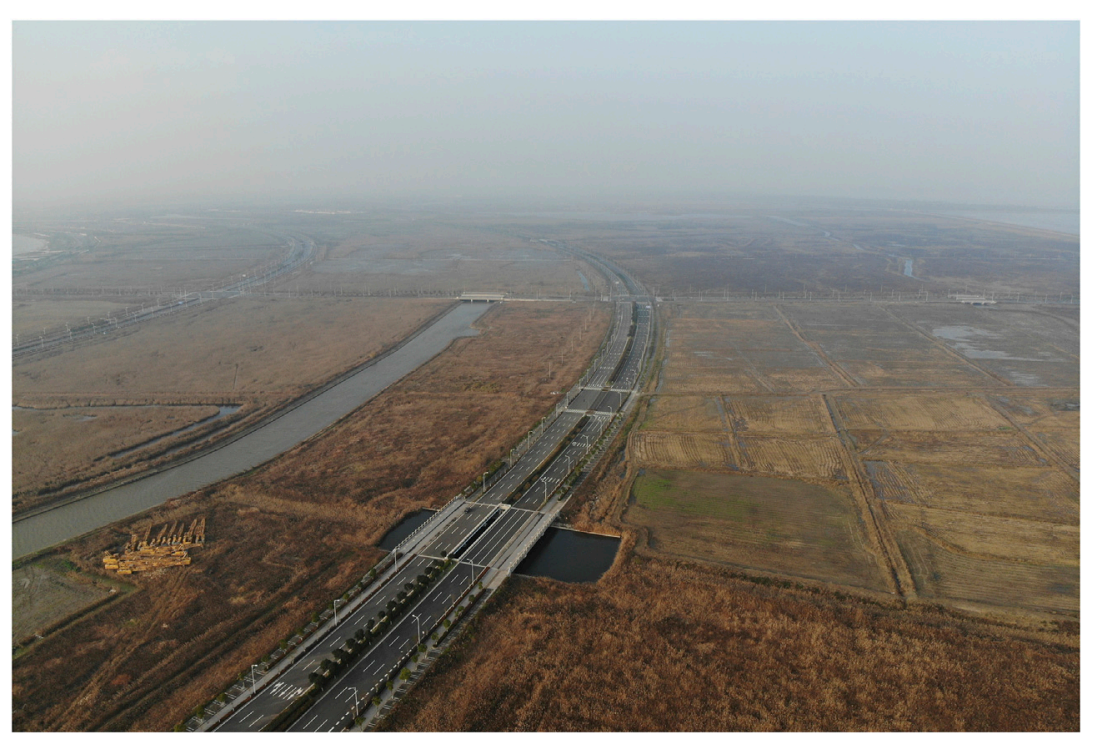

FIGURE 9 | Wetlands partly used for farming at Nanhui in the Pudong District. Lingang New Harbor City was planned here (Photo by author, December 2018).

classification system (Lin, 2009) and consequently are often converted to agriculture. ${ }^{18}$ Many stakeholders underestimate the value of ecosystem services (Wang et al., 2019). Ecological restoration needs understanding and systematic research, since ecosystems are sensitive and complex systems. For example, the soil structure and silt on coastal marshes make it inhospitable for most trees, and especially unsuitable for a cypress plantation, which is the case now ( $\mathrm{Li}, 2020)$. A group of environmentalists, scientists, and nature enthusiasts launched a protest to raise international awareness to counter this threat, especially since Tesla's new Gigafactory started construction near here (Brelsford, 2019).

\section{Chongming Eco-Island}

\section{Expectations and Socio-Technical Experimentation}

Chongming Island, located in the estuary of the Yangtze River lies within the municipal border of Shanghai. The $80 \mathrm{~km}^{2}$ large Dongtan area is a former state farm, located in Chenjia Town one of the 18 administrative subdivisions of Chongming Island. At Dongtan, on the east end of the island, there are two zones appointed as "wetlands of extreme international importance" by the Ramsar Convention, 2018. ${ }^{19}$ Already in 1996 the National Government nominated Chongming as an eco-island, and in 2001 the expectation for this eco-island was "to explore experiences of sustainable development for China's cities and towns and provide excellent model exemplars" (MOST, 2001). It became the site for several experimental projects, including the promising pilot project for Dongtan Eco-city (Den Hartog, 2010). As recently as 2009 , the whole island was designated officially as

\footnotetext{
${ }^{18}$ See this article available online at: http://www.ecns.cn/2015/10-30/186433.shtml (Accessed July 30, 2021).

${ }^{19}$ Chongming Dongtan Nature Reserve, Shanghai, https://rsis.ramsar.org/ris/1144; Shanghai Yangtze Estuarine Wetland Nature Reserve for Chinese Sturgeon, https:// rsis.ramsar.org/ris/1730 (Accessed July 30, 2021).
}

National Experimental Zones for Sustainable Development, and in 2017 this status was upgraded to National Ecological Demonstration Zone (Ma et al., 2017).

\section{Sustainable Innovation Journey and Conflicts With Wetland Restoration Efforts}

The effectiveness of this eco-island-policy becomes clear when studying the northwestern edge of Chongming, which falls under jurisdiction of Jiangsu Province, and is consequently excluded from the National Ecological Demonstration Zone. Serious conflicts in land use arose there when under the guise of protecting land through conservation development (Milder, 2007), natural wetlands were reclaimed and opened up opportunity for massive speculative real estate. This deviation from the intended sustainable innovation journey toward an ecological demonstration zone on the part of the island that isn't administered by Shanghai occurred due to inadequate supervision, and especially poor communication between various responsible authorities at municipal and provincial levels. A profit-seeking developer (Greenland, which is state-owned and Shanghai based) and local governments in Jiangsu Province started a joint project here named "Long Island," which envisaged a new town for 100,000 inhabitants, but it was not inhabited because of its remote location and it has been used for speculative investment (Figures 2, 10, 11; Den Hartog, 2017). This has added to the already severely disturbed ecosystem along the north-branch of the estuary, subject to ongoing degradation since the 1950's (Guo et al., 2021), and prone to flood risk (see Strategic and Exposed Position in the Yangtze River Estuary). Two similar projects were built there as well. After negative media attention, the central government took over control of the project and started to intervene; halting construction and threatening to demolish all newly constructed high-rise buildings, although the buildings remain (Den Hartog 2019).

This experience illustrates that experimental demonstration zones and pilot-projects need thorough preparation and 


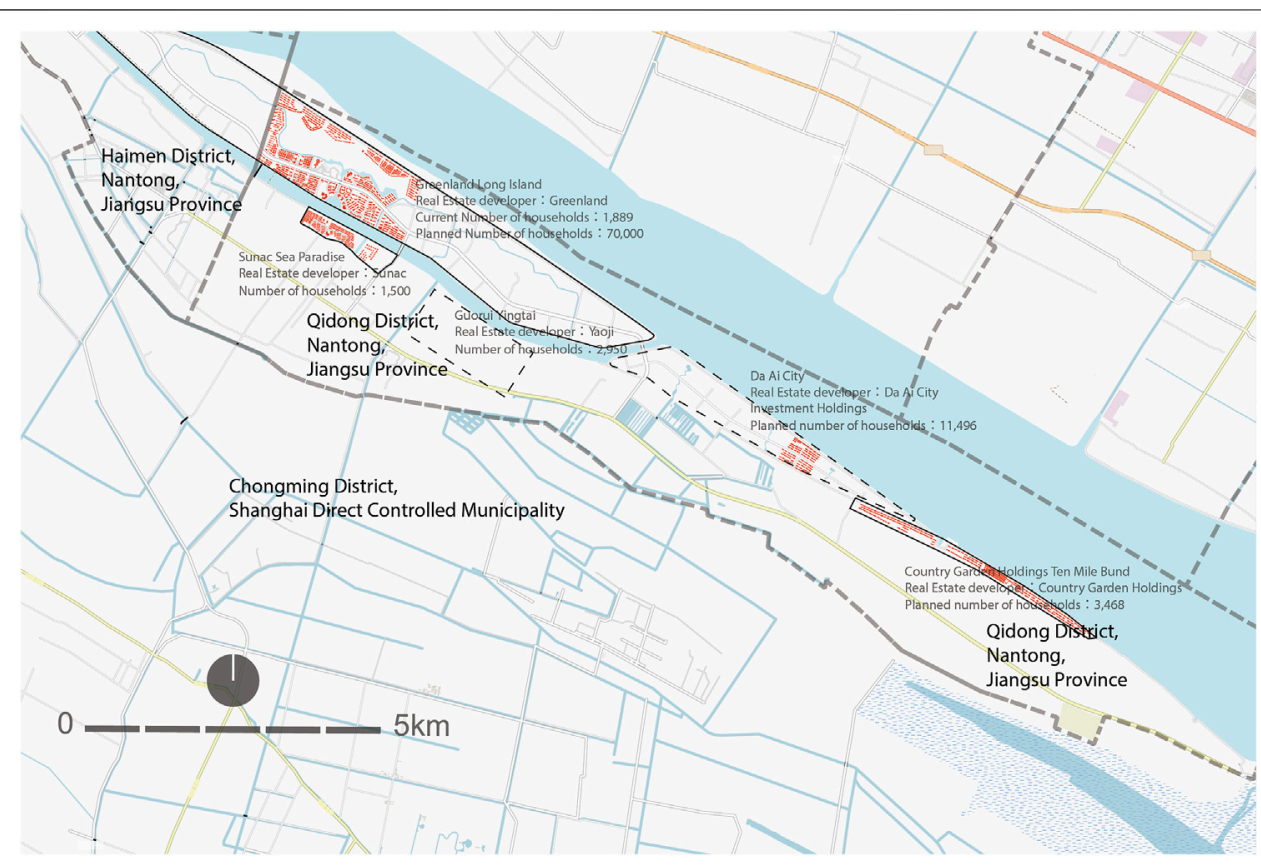

FIGURE 10 | Long Island real estate project and related projects, located in the Jiangsu Province part of Chongming Island, constructed since 2014 on top of more than 12 square kilometers reclaimed wetlands; most buildings are empty (Map by author and Jiawei Hu).

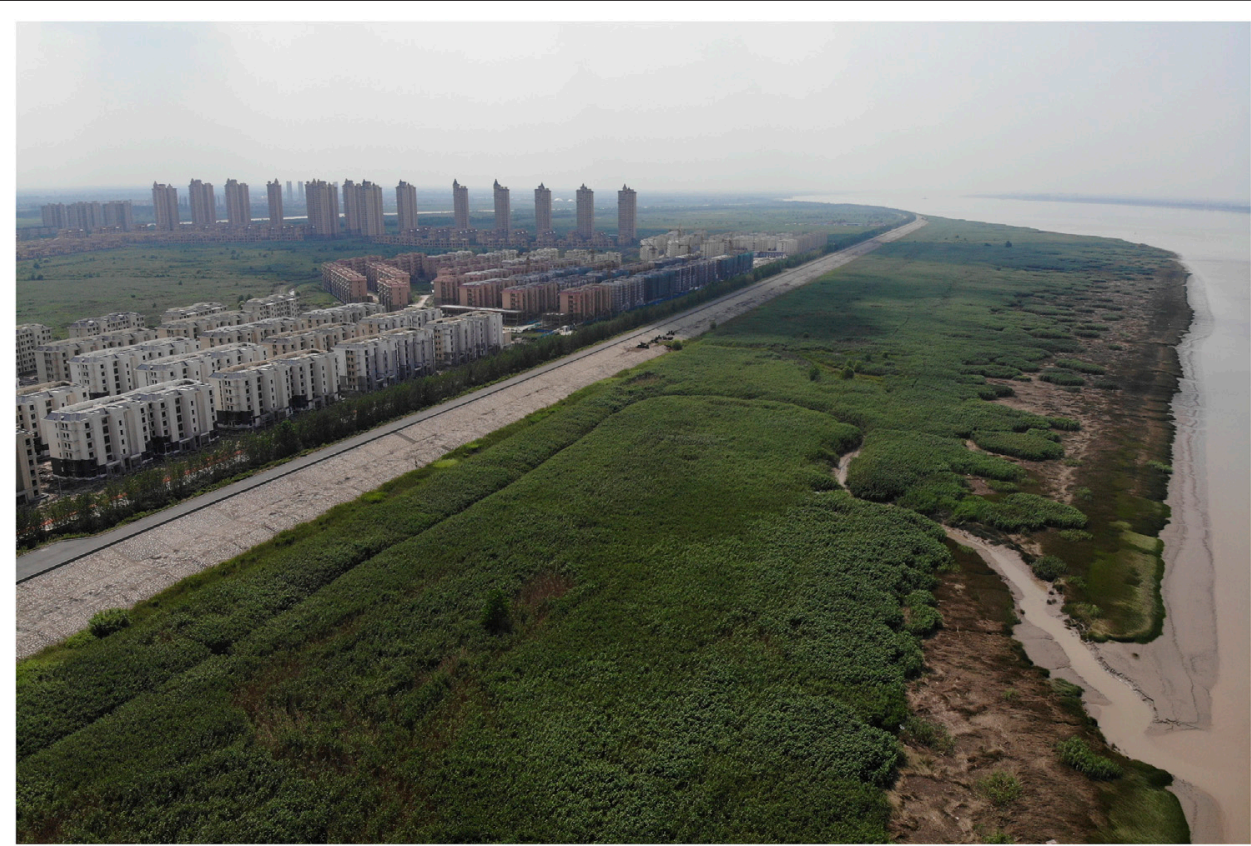

FIGURE 11 | Fragment of the speculative Long Island real estate project in the Jiangsu Province part of Chongming Island (Photo by author, July 2019).

supervision beyond municipal boundaries, and clear communication with all stakeholders. Another example of problems with implementation of this National Ecological Demonstration Zone occurred near the Ramsar zones at the eastern edge of the island. From the early 1990's Spartina alterniflora, an invasive species used to stabilize shoals to make them ready for reclamation, appeared on Chongming Island. As a consequence of its rapid spreading, wetland biodiversity declined (Zou et al., 2014). In parallel, even with the introduction of the National Ecological Demonstration Zone, land reclamation continued, even within natural reserve areas. This 


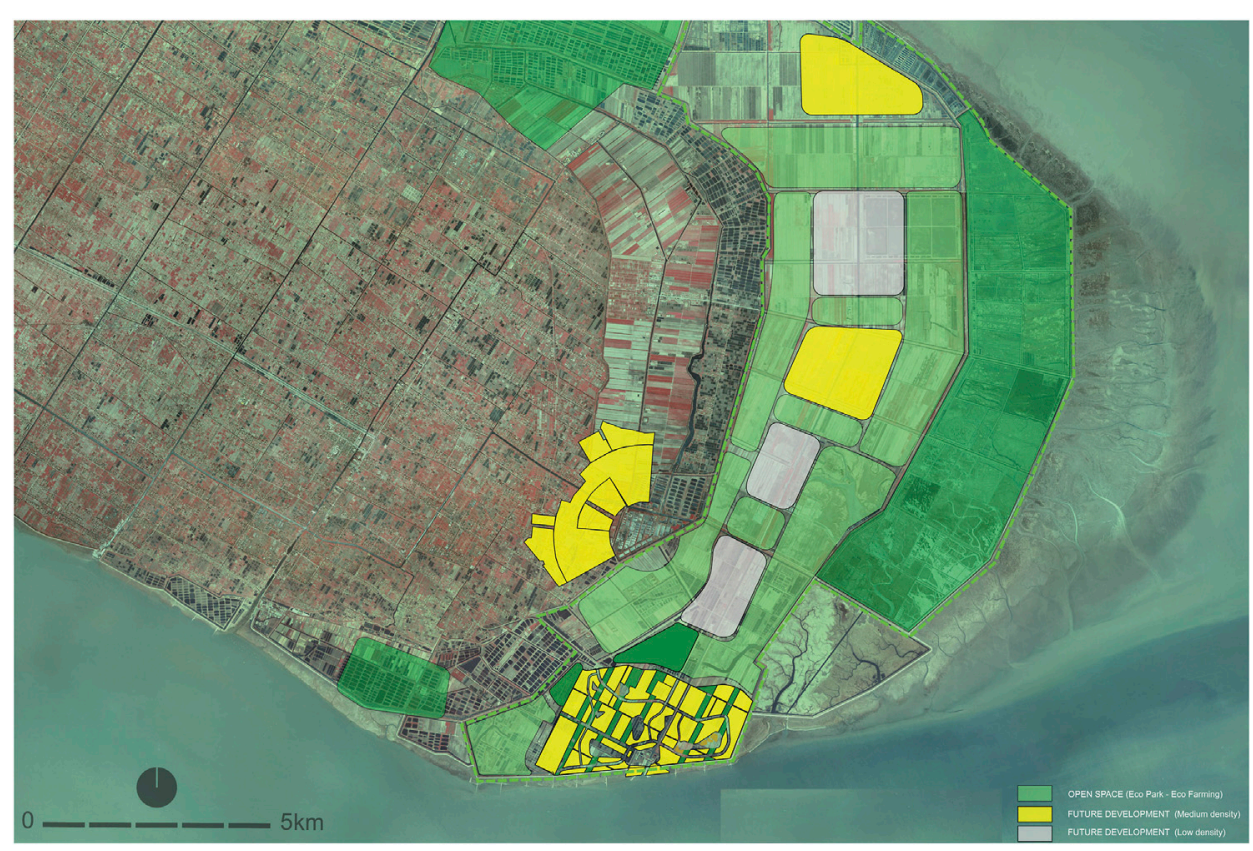

FIGURE 12 | Master plan for Dongtan Eco-city, good for 500,000 inhabitants. The plan has never been realized; resorts with in total more than a thousand speculative (seldom used) luxurious villas and a golf course have been built here instead (Source: Arup, 2005).

happened under the guise of removing invasive plants (Xie et al., 2020).

One of the first actions to counter these practices was the WWFChina Flyways program, which was financially supported by multiple companies including Coca-Cola, and the Kingdom of Netherlands. ${ }^{20}$ This pilot-project started in 2014 and aimed to reduce and control the Spartina alterniflora. The program involved environmental stewardship on Dongtan wetland by involving local communities and farmers, and by introducing principles and practices of waterbird-friendly aquaculture. As a result, the number of waterfowl species has increased significantly (Shanghai Daily, 2017). The innovation journey of Chongming Eco-Island shows that a sustainability transition can't be a readily achievable instant solution. Even in a central controlled State, it is a long-winded process of adjusting and adapting, especially due to its many dimensions and large scale. It includes both successes (e.g. the before-mentioned WWFChina Flyways program) as well as failures, such as the demise of Dongtan Eco-city located besides the Ramsar zones (Figures 2, 12), where luxurious apartments have been built along a golf course, mostly empty, that are used for speculative investment instead of the promised ecological dream city (Den Hartog et al., 2018).

\section{DISCUSSION}

What can we learn from Shanghai's sustainable innovation journey? How might the city improve the balance between wetland protection,

\footnotetext{
${ }^{20}$ See also: https://www.eaaflyway.net/signing-of-the-mou-between-the-chinese-
} state-forestry-administration-and-wwf-china (Accessed July 30, 2021). urban development, and climate change adaptation? The aboveexamined cases show that despite good intentions and central control, expectations can still differ from end results. Apart from advantages in terms of speed, scale and Chinese decisiveness, we can learn that (severe) collateral damage to the environment can still occur, e.g. because of inconsistent definitions of wetlands (see Section Nanhui Coastal Wetland Reserve and Lingang New Harbor City), or because of greed and inadequate communication between different authorities (see Long Island in Section Chongming Eco-Island).

\section{Expectations and Conflicts}

The "statements about the future" (Van Lente, 2012) regarding the econetwork in Shanghai's current master plan are practice-based and challenge-led, and steered by ecological civilization in an attempt to balance environmental, economic, and social aspects. These statements are certainly robust-because state-led, specific, and of high quality (Schot and Geels, 2008). The promises and content of Shanghai 2035 showcases the absorption of international knowledge and practices, and even has the ambition to surpass other global cities in terms of speed, and scale, and quality. The new Huangpu waterfronts are breathtaking. It is remarkable that they were realized in such a short timespan. In addition, the amount of urban greening in the city as a whole, with green buffers and new coastal wetland, all integrated into a new econetwork, largely already under construction, is unprecedented.

This is impressive but distracts from substantive necessary quality and long-term goals. The cases on Chongming (Section Chongming Eco-Island), and along the Huangpu River in downtown Shanghai (Section Huangpu River Waterfront as Main Stage for Ecological Civilization), are primarily aimed at improving the (public) image and status, to attracting (foreign) investment, and to accommodate a selective upper middle class with a comfortable living environment 
(Den Hartog, 2019). This is also a form of environmental injustice and contradicts the principles of an ecological civilization (Pan, 2006). For example, relocation of polluting industries might be good for downtown citizens, but causes conflicts on the new locations of these still polluting industries.

\section{Socio-Technical Experimentation and Learning Factors}

In the Global North, the key role in sustainability transitions shifts from the national governments toward local governments, especially cities (Sengers et al., 2016). Even in a strongly centrally controlled country as China local governments play a decisive role-in the case of Shanghai even on district level as we found in the case studies-and in particular the translation and communication into everyday practice and usages by local people is decisive.

According to Evans et al. (2016) "urban experimentation" could become a new mode of governance that turns cities into laboratories for the future, especially in the context of welfare states that are increasingly under pressure, and "decreasing possibilities of national state actors to shape sustainability transitions" (Sengers et al., 2016). In the European centered discourse Karvonen (2016) claims that this type of experimentation could supplement or even replace traditional urban planning approaches. Karvonen (2016)explains that in the Global North local authorities frequently use it to mask a lack of funding, or to suggest public-private partnerships. In short, it often represents the erosion of the role and responsibilities of the state, by increasingly outsourcing expertise to citizens and non-Government stakeholders.

Yet in the case of Shanghai this is absolutely the opposite due to a very different socio-political setting. In the People's Republic of China the state uses experimental pilot projects and demonstration zones to set standards and guidelines. The pilot-projects and demonstration zones as described in this paper are socio-technical experiments, but differ from urban labs and experiments, in scale, timeframe, and because far fewer stakeholders participate directly in these state-led processes. This makes their innovation journeys less inclusive. The terms "pilot-project" and "demonstration zone" suggest a certain degree of control of the experiment aimed to prevent failure, opposed to the term "urban lab." This makes pilot-projects and demonstration zones different from the definition in Section Sustainability Transitions and Experiments, because experiments do not guarantee success; they can fail (Garud et al., 2014; Sengers et al., 2016). Failure includes a learning factor.

\section{Sustainable Innovation Journey and Civic Engagement}

Limiting participation to a select group of stakeholders also excludes feedback as a possible enabler for learning, e.g., as we saw in Section Chongming Eco-Island (Xie et al., 2020). Yet this means that the implementation speed of pilot-projects and demonstration zones can be accelerated, also because of state ownership and mandate over land and resources. Consequently the state-led approach in Shanghai (China) can be more radical and large-scale. This makes the design and implementation of pilot-projects and demonstration zones less uncertain (Garud et al., 2014) and less open-ended as an unfolding sustainable innovation journey (Van de Ven et al., 1999). Denying learning potential is opposed to an adaptive management approach and a hurdle for system innovation.

In the sustainability transitions discourse, experimental approaches and urban labs are expected to lead to innovative, integrated, and inclusive policies and solutions. This can be more easily achieved if sustainability learning is co-created and shared. Coercive environmentalism is certainly no guarantee for successful sustainable solutions (Li and Shapiro, 2020). Actually public participation and consultation were included in China's constitution during Mao's reign, but neglected afterwards. Participation needs to be reprioritized again, including in China's environmental policymaking, according to Li and Shapiro (2020). As indicated in Section Toward an Ecological Civilization, ecological civilization calls for new balances between top-down and bottom-up governance approaches and new forms of participation, which is underlined in Shanghai 2035, but is still in an elementary phase in practice. Consultation and transparency are essential to realize a true ecological civilization. Feedback from civil society will improve the outcomes from pilot-projects and demonstration projects, and will likely make policies more effective and sustainable. Yet, this is less likely under the current prevailing Chinese system of governance, as can be seen in the urban regeneration processes along the Huangpu River that lack an inclusive approach ( $\mathrm{Li}$ and Zhong, 2020; Den Hartog, 2021).

This complexity underscores that a true ecological civilization involves an innovation journey of gradual adjustment and understanding, which cannot be implemented top-down at once, but needs to be more inclusive with a wide variety of societal stakeholders, e.g., such as happened at the initiative of the WWF on Chongming Eco-Island (see Chongming Eco-Island) and the use of incentives to stimulate grassroots experiments with eco-farmers (Den Hartog et al., 2018).

\section{CONCLUSION AND RECOMMENDATIONS}

It is encouraging that China, with Shanghai as a frontrunner, is attempting to restore ${ }^{21}$ the damage done by radical urbanization to the natural environment. Based on the findings in the case studies and the discussion in the discussion some concluding recommendations can be made, aimed to reduce discrepancies between expectations and the reality of daily life. Despite Shanghai's intentions to raise awareness about environmental challenges and its ambition to play a leading role in enabling a green transition, there are still hurdles to be faced.

\section{Expectations Need to be Co-Created and Shared}

To translate expectations into realities on the ground these expectations need shared understanding, including agreed

\footnotetext{
${ }^{21}$ In 2018 China's State Council launched a new regulation on land reclamation to further protect coastal wetlands (State Council, 2018), hopefully more adequate than previous rules. Also see this criticism online: https://chinadialogue.net/en/ nature/9814-will-china-s-new-wetlands-protection-rules-be-adequate (Accessed July 30,2021$)$.
} 
definitions of key concepts, to prevent problems as occurred in Nanhui (Nanhui Coastal Wetland Reserve and Lingang New Harbor City) and Long Island (Chongming Eco-Island) where the appreciation and evaluation of ecological assets such as wetlands differed amongst various stakeholders. During fieldwork it became clear that terms like "green" and "ecology" are primarily used for making a place visually attractive instead of to increase biodiversity. Policy terms as "beautification" and "harmonization" create high expectations, but may not be realized in daily-life if their intended meaning is not robust (shared by all actors) and not specific (Schot and Geels, 2008). There is a worrying discrepancy in the evaluation of ecosystem services and the daily-life use and protection of wetlands. Therefore a main concern is to acknowledge these ecosystem services. To build shared expectation, the first recommendation is to use widely understood definitions, supported by local leaders and well informed by scientists (e.g. universities and nature conservation organizations) and to communicate this understanding clearly with all stakeholders to guide the innovation journey toward urban sustainability and ecological civilization (recommendation 1).

A co-created shared vision is essential to realize a sustainable innovation journey (Geels et al., 2008) in the long run. Also in line with the ecological civilization philosophy and participation traditions (Li and Shapiro, 2020), new ways of involving citizens in State-led processes need to be explored, to co-create a shared vision for the future, and by working with communities to better understand their needs and aspirations (recommendation 2).

\section{Socio-Technical Experimentation Requires Research About Needs and Consequences}

The experimental new cities Lingang (Nanhui Coastal Wetland Reserve and Lingang New Harbor City) and Dongtan (Chongming Eco-Island), as well as the commercial development on Long Island (Chongming Eco-Island), are all constructed on exposed and vulnerable locations, in conflict with existing ecological values (Cui et al., 2015), and subject to flood risk (Wang et al., 2015). Additionally all three mentioned locations have problems with attracting inhabitants because of their remote locations and disturbing speculative ownership_-most building are used as investment objects, especially as second houses by new middle-class families in Shanghai-, resulting in desolate communities and a waste of resources. ${ }^{22}$ This conflicts sharply with the international accepted definition of sustainability (United Nations, 1987) and also with the idea of harmonious interaction with nature as in ecological civilization. It is recommended that clear policy guidelines are developed to guide property development to ensure public safety and sustainability including wetland protection (recommendation 3).

\section{A Sustainable Innovation Journey Should be a Social Learning Journey and This can Benefit From Citizen Engagement}

A sustainable innovation journey needs to be developed through a joint experimental learning approach-e.g., by approaching

${ }^{22}$ Well-known designers and engineers from the Global North designed the master plans for these three new cities. wetlands as valuable asset with ecosystem services-to be able to effectively protect the remaining wetlands. If an experiment is codefined as being inclusive and "designed to promote system innovation through social learning" (Sengers et al., 2016) it is essential to involve more actors who are willing to engage and to foster social learning (Loorbach, 2007), including farmers, fishermen, and users in daily life (recommendation 4).

In China, local governments generally have a decisive executive role, while the higher levels of government (provincial and national) have more of a policy-prescribing and supervisory role. Due to various reasons (e.g., lack of experience, time pressure, mismanagement) sometimes things go wrong at local executive level. To prevent this supervision is essential during all stages, and beyond (municipal) planning boundaries (recommendation 5) - e.g., in the case of Long Island (Chongming Eco-Island) a supervising team was formed after the damage was done, because the responsible officials could not and did not want to exert influence on the other sides of the municipal and provincial border line.

China, with Shanghai ahead, is shifting from a production economy towards an urban consumption society. During the innovation journey of trial and error, there is a search for a harmonious balance between wetland protection, urban development (including economic aspects, social aspects, etcetera), and climate change adaptation. At the moment it is too early to draw conclusions on the functioning of the new ecological corridors, since only some of them have been implemented so far. Ecological civilization has an anthropocentric emphasis, which is understandable in the context of extreme high population density and the desire for economic catch-up. But to be fully sustainable, ecofriendly and effective in reducing risks (Greenpeace East Asia, 2021) caused by climate change and to restore ecosystems (UN Environment, 2019), there is an urgent need to step beyond this anthropocentric approach (recommendation 6).

Another recommendation is to recognize the reality of uncertainty and ambiguity during the innovation journey of experimentation, to create conditions and opportunities for deliberate social learning and policy adjustments, and correct and steer the project at an earlier stage with creative planning and decision-making processes that are more experimental in nature (recommendation 7).

More thoughtful and better-prepared experiments are urgently needed to further establish Shanghai as a world-leading lab for sustainable urban planning and design, and to fulfill the sustainability transition journey toward achieving the Sustainable Development Goals (UN Habitat, 2015) and also the goals of an ecological civilization. Shanghai's journey differs from established cities in the Global North, ${ }^{23}$ and needs to deal with a different audience, with a different background, experience and life-style. Consequently there are other priorities and expectations. The innovation journey towards an ecological civilization will have significant impact on daily life in

\footnotetext{
${ }^{23}$ Environmental pressure in China rose quickly last few decades due to extreme urbanization. Additionally we need to realize that a large share of the polluting industries that contributed to the environmental pressure are relocated (to Shanghai) from countries in the Global North, partly as result of carbon trading policies (Pan, 2006). Meanwhile China is currently outsourcing a lot of its environmental degradation to other countries, for example timber trafficking, see: https://newsroom.ucla.edu/releases/furniture-from-china-contributes-todeforestation-in-central-africa (Accessed July 30, 2021).
} 
China, and far beyond. The expectations as described in the current master plan span till 2035, thus many unforeseen changes will occur. Hence it remains a journey full of uncertainty.

\section{DATA AVAILABILITY STATEMENT}

The raw data supporting the conclusion of this article will be made available by the authors, without undue reservation.

\section{ETHICS STATEMENT}

Ethical review and approval was not required for the study on human participants, in accordance with the local legislation and institutional requirements. The participants provided their written informed consent to participate in this study.

\section{REFERENCES}

Balica, S. F., Wright, N. G., and van der Meulen, F. (2012). A Flood Vulnerability Index for Coastal Cities and its Use in Assessing Climate Change Impacts. Nat. Hazards 64 (1), 73-105. doi:10.1007/s11069-012-0234-1

Ball, P. (2017). The Water Kingdom: A Secret History of China. Chicago: University Of Chicago Press.

Borup, M., Brown, N., Konrad, K., and Van Lente, H. (2006). The sociology of expectations in science and technology. Tech. Anal. Strateg. Manag. 18 (3-4), 285-298. doi:10.1080/09537320600777002

Brelsford, C. (2019). Letter to Elon Musk. Available online at: https://www. shanghaibirding.com/musk (Accessed July 30, 2021).

Brown, L. (1995). Who Will Feed China? Wakeup call for a small planet. New York: W. W. Norton.

Chen, L., and Du, F. (2018). Practice and exploration on Shanghai territory spatial planning from the perspective of Ecological Civilization. J. Land Spat. Plann. (Translated from Chinese). doi:10.11982/j.supr.20190401

Cui, L., Ge, Z., Yuan, L., and Zhang, L. (2015). Vulnerability assessment of the coastal wetlands in the Yangtze Estuary, China to sea-level rise. Estuarine, Coastal Shelf Sci. 156, 42-51. doi:10.1016/j.ecss.2014.06.015

Danley, B., and Widmark, C. (2016). Evaluating conceptual definitions of ecosystem services and their implications. Ecol. Econ. 126, 132-138. doi:10.1016/j.ecolecon.2016.04.003

Den Hartog, H. (2019). Re-defining the appreciation and usability of urban watersides in the urban center and peri-urban fringes of Shanghai. Eur. J. Creat. Practices Cities Landscapes 2 (1), P37-P64. doi:10.6092/issn.26120496/8918

Den Hartog, H. (2010). Shanghai New Towns - Searching for community and identity in a sprawling metropolis. Rotterdam: 010 Publishers.

Den Hartog, H. (2017). Rural to Urban Transitions at Shanghai's Fringes. IRSPSD Int. 5 (4), 54-72. doi:10.14246/irspsd.5.4_54

Den Hartog, H., Sengers, F., Xu, Y., Xie, L., Jiang, P., and De Jong, M. (2018). Lowcarbon promises and realities: Lessons from three socio-technical experiments in Shanghai. J. Clean. Prod. 181, 692-702. doi:10.1016/j.jclepro.2018.02.003

Den Hartog, H. (2021). Shanghai's Regenerated Industrial Waterfronts: Urban Lab for Sustainability Transitions? Up 6 (Issue), 181-196. doi:10.17645/ up.v6i3.41943

Evans, J., Karvonen, A., Raven, R., and Raven, R. (2016). “The experimental city,” in The Experimental City. Editors J. Evans, A. Karvonen, and R. Raven (London, UK; New York, USA: Routledge), 1-12. doi:10.4324/9781315719825-1

Frazier, A. E., Bryan, B. A., and Buyantuev, A. (2019). Ecological civilization: perspectives from landscape ecology and landscape sustainability science. Landscape Ecol. 34, 1-8. doi:10.1007/s10980-019-00772-4

Gan, J., Deng, X., and Guo, G. (2018). Planning Control Strategies and Development Guidelines for Waterfront Ecological Space in High- Density

\section{AUTHOR CONTRIBUTIONS}

The author confirms being the sole contributor of this work and has approved it for publication.

\section{ACKNOWLEDGMENTS}

Thanks to all who were willing to share their experiences. Thanks to Xiyan Yang and Jiawei Hu for helping me with collecting and translating basic data. Thanks to students that participated in my course "City and Environment" at Shanghai University of Finance and Economics between 2015 and 2019, and students from Tongji University that participated in related research and design studio's, for giving me new insights during our discussions and site visits.

Urban Area: Take Waterfront Area along Huangpu River and Suzhou Creek in Shanghai as Examples. Urban Plann. Forum 5, 63-70. (in Chinese).

Gare, A. (2020). The Eco-socialist Roots of Ecological Civilization. Capitalism Nat. Socialism 32 (1), 37-55. doi:10.1080/10455752.2020.1751223

Garud, R., Gehman, J., and Giuliani, A. P. (2014). Contextualizing entrepreneurial innovation: A narrative perspective. Res. Pol. 43, 1177-1188. doi:10.1016/ j.respol.2014.04.015

Geels, F., Hekkert, M., and Jacobsson, S. (2008). The dynamics of sustainable innovation journeys. Tech. Anal. Strateg. Manag. 20 (5), 521-536. doi:10.1080/ 09537320802292982

Greenpeace East Asia (2021). Greenpeace maps growing climate risk from extreme weather in China's major cities. Available online at: https:// www.greenpeace.org/eastasia/press/6727/greenpeace-maps-growingclimate-risk-from-extreme-weather-in-chinas-major-cities/ (Accessed July 30, 2021).

Guo, C. (2018). Exploration on "Shanghai 2035” Ecological Space Planning. J. Land Spat. Plann. (Translated from Chinese). doi:10.11982/ j.supr.20180519

Guo, L., Xie, W., Xu, F., Wang, X., Zhu, C., Meng, Y., et al. (2021). A historical review of sediment export-import shift in the North Branch of Changjiang Estuary. Earth Surf. Process. Landforms., 1-13. doi:10.1002/esp.5084

Hansen, M. H., Li, H., and Svarverud, R. (2018). Ecological civilization: Interpreting the Chinese past, projecting the global future. Glob. Environ. Change 53, 195-203. doi:10.1016/j.gloenvcha.2018.09.014

Hansen, M. H., and Liu, Z. (2017). Air pollution and grassroots echoes of "Ecological Civilization" in Rural China. UK: Cambridge University Press.

Hanson, S., Nicholls, R., Ranger, N., Hallegatte, S., Corfee-Morlot, J., Herweijer, C., et al. (2011). A global ranking of port cities with high exposure to climate extremes. Climatic change 104, 89-111. doi:10.1007/s10584-010-9977-4

Harvey, D. (2005). "Chapter 5 Neoliberalism 'with Chinese Characteristics," in A Brief History of Neoliberalism (New York: Oxford University Press), 120-151.

Hsing, Y. (2010). The Great Urban Transformation: Politics of Land and Property in China. New York: Oxford University Press.

IPCC (2019). IPCC Special Report on the Ocean and Cryosphere in a Changing Climate. Available online at: https://www.ipcc.ch/srocc/cite-report/ (Accessed July 30,2021$)$.

Jin, L. (2020). Researching ways to demarcate the ecological protection red line in Shanghai by classifying ecological space management. J. Land Resour. 41, 2. doi:10.3969/j.issn.2095-1329.2020.02.002

Karvonen, A. (2016). Andrew Karvonen on Experiments and Urban Living Labs. NordRegio.

Ke, Q. (2014). Flood risk analysis for metropolitan areas - a case study for Shanghai. the Netherlands: Delft Academic Press. doi:10.4233/uuid:61986b2d-72de-45e78f2a-bd61c725325d

King, F. H. (1911). Farmers of Forty Centuries: Or, Permanent Agriculture in China, Korea and Japan. Madison, Wisconsin: Democrat Printing Co. 
Kivimaa, P., Hildén, M., Huitema, D., Jordan, A., and Newig, J. (2017). Experiments in climate governance - A systematic review of research on energy and built environment transitions. J. Clean. Prod. 169, 17-29. doi:10.1016/j.jclepro.2017.01.027

Konrad, K. (2006). The social dynamics of expectations: The interaction of collective and actor-specific expectations on electronic commerce and interactive television. Tech. Anal. Strateg. Manag. 18 (3-4), 429-444. doi:10.1080/09537320600777192

Larson, C. (2015). China's vanishing coastal wetlands are nearing critical red line. Available online at: https://www.sciencemag.org/news/2015/10/china-svanishing-coastal-wetlands-are-nearing-critical-red-line (Accessed July 30, 2021).doi:10.1126/science.aad4759

Li, X. (2019). "The Coastal Wetlands in the "Great Protection of the Yangtze River" Are indispensable, and it is not feasible to focus on construction but despise protection," in Research in Nanhui Dongtan. Available online at: http://www. cbcgdf.org/NewsShow/4854/9396.html (Accessed July 30, 2021).

Li, X., Zhang, X., Qiu, C., Duan, Y., Liu, S., Chen, D., et al. (2020). Rapid loss of tidal flats in the Yangtze River Delta since 1974. Int. J. Environ. Res. Public Health 17 (5), 1636. doi:10.3390/ijerph17051636

Li, Y., and Shapiro, J. (2020). China Goes Green: Coercive Environmentalism for a Troubled Planet. Polity Cambridge, United Kingdom: Polity Press.

Li, Y. (2020). The fierce debate over Shanghai's new forest. Sixth Tone. Available online at: https://www.sixthtone.com/news/1005686/the-fierce-debate-o (Accessed July 30, 2021).

Li, Y., and Zhong, X. (2020). 'For the People' without 'By the People': People and Plans in Shanghai's Waterfront Development. Int. J. Urban Reg. Res.. doi:10.1111/1468-2427.12964

Lin, G. C. (2009). Developing China: Land, Politics and Social Conditions. London: Routledge Contemporary China Series.

Linster, M., and Yang, C. (2018). China's Progress Towards Green Growth: an international perspective. OECD Green Growth Papers, No. 2018/05. Paris: OECD Publishing.

Liu, X., Li, Li., Zhou, Y., Chen, Z., and Ding, Y. (2019). Analysis of landscape ecological pattern evolution and eco-network structure optimization for Shanghai. Resour. Environ. Yangtze Basin 28, 10, 2019 . (Translated from Chinese).

Loorbach, D. (2007). Transition Management: New Mode of Governance for Sustainable Development. Utrecht: International Books.

Ma, X., De Jong, M., and Den Hartog, H. (2017). Assessing the implementation of the Chongming Eco Island policy: What a broad planning evaluation framework tells more than technocratic indicator systems. J. Clean. Prod. 172, 872-886. doi:10.1016/j.jclepro.2017.10.133

Markard, J., Raven, R., and Truffer, B. (2012). Sustainability transitions: an emerging field of research and its prospects. Res. Pol. 41, 955-967. doi:10.1016/j.respol.2012.02.013

Milder, J. C. (2007). A Framework for Understanding Conservation Development and its Ecological Implications. BioScience 57, 757-768. doi:10.1641/B570908

Moeller, I., Kudella, M., Rupprecht, F., Spencer, T., Paul, M., Van Wesenbeeck, B. K., et al. (2014). Wave attenuation over coastal salt marshes under storm surge conditions. Natl. Geosci. 7, 727-731.

MOST (2001). The notice regarding the issue of Regulation of National Experimental Zones for Sustainable Development. Available online at: http://www.most.gov.cn/fggw/zfwj/zfwj2001/200512/t20051214_55012.htm (Accessed July 30, 2021).

Pan, Y. (2006). The rich consume and the poor suffer the pollution. Available online at: https://chinadialogue.net/en/business/493-the-rich-consume-andthe-poor-suffer-the-pollution (Accessed July 30, 2021).

Quan, R. (2014). Risk assessment of flood disaster in Shanghai based on spatial-temporal characteristics analysis from 251 to 2000. Environ. Earth Sci. 72, 4627-4638. doi:10.1007/s12665-014-3360-02014

Ramsar Convention (2018). Available online at: https://www.ramsar.org/news/ wetlands-worlds-most-valuable-ecosystem-disappearing-three-times-fasterthan-forests-warns-new (Accessed July 30, 2021).

Schot, J., and Geels, F. (2008). Strategic niche management and sustainable innovation journeys: theory, findings, research agenda and policy. Techonoly Analalysis Strateg. Manag. 20 (5), 537-554. doi:10.1080/ 09537320802292651
Sengers, F., Wieczorek, A. J., and Raven, R. (2016). Experimenting for sustainability transitions: A systematic literature review. Technol. Forecast. Soc. Change 145, 153-164. doi:10.1016/j.techfore.2016.08.031

Shanghai Daily (2017). Reviving the Chongming Dongtan Wetland. Available online at: https://archive.shine.cn/supplement/Reviving-the-ChongmingDongtan-Wetland/shdaily.shtml (Accessed July 30, 2021).

Shanghai Planning and Land Resource Administration (SPLRA) (2018a). Shanghai Master Plan 2017 - 2035. For this research I used a full version; a public version in English is as summary available online at: https://ghzyj.sh.gov.cn/ghjh/ 20200110/0032-811864.html (Accessed July 30, 2021).

Shanghai Planning and Land Resource Administration (SPLRA) (2018b). Striving for a world-class waterfront area - Shanghai Huangpu River and Suzhou River planning. Available online (in Chinese) at: http://www.shjx.org.cn/article17574.aspx (Accessed July 30, 2021).

Shapiro, J. (2001). Mao's War against Nature: Politics and the Environment in Revolutionary China. Cambridge: Cambridge University Press.

State Council (2018). Notice on Strengthening Coastal Wetland Protection. Available online at: http://www.gov.cn/zhengce/content/2018-07/25/content 5309058.htm (Accessed July 30, 2021).

Sutton-Grier, A., and Howard, J. (2018). Coastal wetlands are the best marine carbon sink for climate mitigation. Front. Ecol. Environ. 16 (Issue 2), 73-74. doi:10.1002/fee.1766

Tian, B., Zhou, Y. X., Thom, R. M., Diefenderfer, H. L., and Yuan, Q. (2015). Detecting wetland changes in Shanghai, China using FORMOSAT and Landsat TM imagery. J. Hydrol. 529 (1), 1-10. doi:10.1016/ j.jhydrol.2015.07.007

UN Climate Change News (2018). Wetlands Disappearing Three Times Faster than Forests. Available online at: https://unfccc.int/news/wetlandsdisappearing-three-times-faster-than-forests (Accessed July 30, 2021).

UN Environment (2019). Available online at: https://www.unenvironment.org/ news-and-stories/press-release/new-un-decade-ecosystem-restoration-offersunparalleled-opportunity (Accessed July 30, 2021).

UN Habitat (2015). The 2030 Agenda for Sustainable Development. New York, NY: United Nations. Available online at: https://sdgs.un.org/goals (Accessed July 30, 2021).

United Nations (1987). The Brundtland Report: Our Common Future. Available online at: https://sustainabledevelopment.un.org/content/documents/5987ourcommon-future.pdf (Accessed July 30, 2021).

Van de Ven, A., Polley, D., Garud, R., and Venkataraman, S. (1999). The Innovation Journey. New York: Oxford University Press.

Van Lente, H. (2012). Navigating foresight in a sea of expectations: lessons from the sociology of expectations. Tech. Anal. Strateg. Manag. 24 (8), 769-782. doi:10.1080/09537325.2012.715478

Wang, J. (2012). "Eco-Services for Urban Sustainability in the Yangtze River Delta of China: Strategies for Physical Form and Planning". (PhD), Melbourne School of Design, Faculty of Architecture, Building and Planning, The University of Melbourne.Melbourne

Wang, J., Chen, S., and Wang, M. (2019). How Do Spatial Patterns Impact Regulation of Water-Related Ecosystem Services? Insights from a New Town Development in the Yangtze River Delta, China. Sustainability 11 (7), 2010. doi:10.3390/su11072010

Wang, Y., Zhao, L., Yang, D., and Moses, M. (2015). GIS-based climate change vulnerability mapping at the urban scale: a case study of Shanghai metropolitan area in China. Int. J. Environ. Stud. 72 (6), 1002-1016. doi:10.1080/ 00207233.2015.1114750

Wang, Z., He, H., and Fan, M. (2014). The Ecological Civilization Debate in China the Role of Ecological Marxism and Constructive Postmodernism - beyond the Predicament of Legislation. Available online at: http://monthlyreview.org/ 2014/11/01/the-ecological-civilization-debate-in-china (Accessed July 30, 2021)

Wang-Kaeding, H. (2018). What Does Xi Jinping's New Phrase 'Ecological Civilization' Mean? an investigation of the phrase is pressing. The Diplomat. Available online at: https://thediplomat.com/2018/03/whatdoes-xi-jinpings-new-phrase-ecological-civilization-mean (Accessed July 30, 2021).

Weiland, S., Bleicher, A., Polzin, C., Rauschmayer, F., and Rode, J. (2017). The nature of experiments for sustainability transformations: A search for common ground. J. Clean. Prod. 169, 30-38. doi:10.1016/j.jclepro.2017.06.182 
Xian, S., Yin, J., Lin, N., and Oppenheimer, M. (2018). Influence of Risk Factors and Past Events on Flood Resilience in Coastal Megacities: Comparative Analysis of NYC and Shanghai. Sci. Total Environ. 610-611, 1251-1261. doi:10.1016/ j.scitotenv.2017.07.229

Xie, L., Mauch, C., Tan-Mullins, M., and Cheshmehzangi, A. (2020). Disappearing reeds on Chongming Island: An environmental micro history of Chinese ecodevelopment. Nat. Space. doi:10.1177/2514848620974375

$\mathrm{Xu}, \mathrm{Y}$., Liao, Z., and Liu, S. (2017). New concept, new goals, and new model: reflection and exploration on the transformation of Shanghai megacity. City Plann. Rev. 41, 8. doi:10.1039/c7nj00848a

Yang, S. L., Zhang, J., Zhu, J., Smith, J. P., Dai, S. B., Gao, A., et al. (2005). Impact of dams on Yangtze River sediment supply to the sea and delta intertidal wetland response. J. Geophys. Res. 110, F03006. doi:10.1029/ 2004JF000271

Zhang, L., Mol, P. J. A., and Sonnenfeld, A. D. (2007). The interpretation of ecological modernization in China. Environ. Polit. 16, 659-668. doi:10.1080/ 09644010701419170

Zhao, S. Q., Da, L. J., Tang, Z. Y., Fang, H. J., Song, K., and Fang, J. Y. (2006). Ecological consequences of rapid urban expansion: Shanghai, China. Front. Ecol. Environ. 4 (7), 341-346. doi:10.1890/1540-9295(2006)004[0341:ecorue] 2.0.co;2
Zou, Y., Liu, J., Yang, X., Zhang, M., Tang, C., and Wang, T. (2014). Impact of coastal wetland restoration strategies in the chongming dongtan wetlands, china: waterbird community composition as an indicator. Acta Zoologica Academiae Scientiarum Hungaricae 60 (2), 185-198.

Conflict of Interest: The author declares that the research was conducted in the absence of any commercial or financial relationships that could be construed as a potential conflict of interest.

Publisher's Note: All claims expressed in this article are solely those of the authors and do not necessarily represent those of their affiliated organizations, or those of the publisher, the editors and the reviewers. Any product that may be evaluated in this article, or claim that may be made by its manufacturer, is not guaranteed or endorsed by the publisher.

Copyright (C) 2021 Den Hartog. This is an open-access article distributed under the terms of the Creative Commons Attribution License (CC BY). The use, distribution or reproduction in other forums is permitted, provided the original author(s) and the copyright owner(s) are credited and that the original publication in this journal is cited, in accordance with accepted academic practice. No use, distribution or reproduction is permitted which does not comply with these terms. 